\title{
A Cat Skeleton from the Balatlar Church Excavation, Sinop, Turkey
}

\author{
Vedat Onar ${ }^{1, *(\mathbb{D})}$, Gülgün Köroğlu ${ }^{2}$, Altan Armutak ${ }^{3}$, Öğül Emre Öncü ${ }^{4}{ }^{\oplus}$, Abu B. Siddiq ${ }^{5}$ \\ and Aleksander Chrószcz ${ }^{6}$
}

Citation: Onar, V.; Köroğlu, G.;

Armutak, A.; Öncü, Ö.E.; Siddiq, A.B.; Chrószcz, A. A Cat Skeleton from the Balatlar Church Excavation, Sinop,

Turkey. Animals 2021, 11, 288.

https://doi.org/10.3390/ani11020288

Academic Editors: Marina Von

Keyserlingk

Received: 21 December 2020

Accepted: 21 January 2021

Published: 23 January 2021

Publisher's Note: MDPI stays neutral with regard to jurisdictional claims in published maps and institutional affiliations.

Copyright: (c) 2021 by the authors. Licensee MDPI, Basel, Switzerland. This article is an open access article distributed under the terms and conditions of the Creative Commons Attribution (CC BY) license (https:// creativecommons.org/licenses/by/ $4.0 /)$.
1 Osteoarchaeology Practice and Research Centre and Department of Anatomy, Istanbul University-Cerrahpaşa, 34320 Istanbul, Turkey

2 Division of the Art History, Bomonti Campus, Mimar Sinan Fine Art University, 34380 Istanbul, Turkey; gulgun.koroglu.27@hotmail.com

3 Osteoarchaeology Practice and Research Centre and Department of Veterinary History and Deontology, Istanbul University-Cerrahpaşa, 34320 Istanbul, Turkey; armutak@istanbul.edu.tr

4 Istanbul Archaeological Museum, Osman Hamdi Bey Street, 34122 Istanbul, Turkey; oeoncu@gmail.com

5 Department of Anthropology, Mardin Artuklu University, 47200 Mardin, Turkey; abubakarsiddiq@artuklu.edu.tr

6 Department of Biostructure and Animal Physiology, Wrocław University of Environmental and Life Sciences, Kożuchowska 1, 51-631 Wrocław, Poland; aleksander.chroszcz@upwr.edu.pl

* Correspondence: onar@istanbul.edu.tr

Simple Summary: A cat skeleton was unearthed during the 2015 excavation season at the Early Byzantine Balatlar Church complex, by the northeastern Black Sea coast of Turkey. The cat was buried with a human individual. The inhumation was dated back to the period between the end of the 6th century AD and the first half of the 7th century AD. The sex of the human individual remains unknown and the cat has been identified as a female house cat. The skeletal remains in the region of the abdominal cavity, occupied by the stomach in living animal, revealed the remains of a rodent and a house sparrow, eaten only recently prior to cat's death. This can be interpreted as an indirect proof of the cat's role as an efficient pest controller, alongside that of being a pet animal. Presenting the zooarchaeological and archaeological evidence, we argue that the Balatlar cat and her possible owner in the "2015-Grave-14" burial chamber demonstrate the most significant direct archaeological evidence of a cat-human relationship in the Byzantine world so far.

Abstract: In the 2015 excavation season, an east-west oriented burial (2015-Grave-14) built with large dimension stone blocks was unearthed on the south edge of "Area IVi" at the Balatlar Church in Sinop, on the northeastern Black Sea coast of Turkey. In this grave, which is dated between the end of the 6th century AD and the first half of the 7th century AD, a human skeleton was found with the head to the west and a cat skeleton was carefully placed next to the right femur. This study on the burial and the cat skeleton within it shows that, compared to the Roman period, the status of cats reached a higher level during the Byzantine period. It was found that alongside of being a pet, the Balatlar cat was a young healthy female individual that instinctively hunted rodents and birds, given that the remains of a rat and a sparrow were found in the region of the abdominal cavity, corresponding with the stomach location in the living animal. The grave presents the most significant direct archaeological evidence of a pet-human bond recorded at any Byzantine site so far.

Keywords: cat burial; byzantine pet; balatlar church excavation; Felis catus; Turkey

\section{Introduction}

Human-cat relationships in the modern world are claimed to have developed and reached a significant level through a long historical process. However, there is still scare archaeological evidence of the domestication of these animals [1]. Egypt is considered as 
the center from which the domestic cat spread around the Old World [2]. In particular, ancient DNA analyses have proven different routes of domestic cat migration, from Egypt to different other parts of the Ancient World [3]. In this way, the variety and wider distribution of domestic cat populations originated and increased [1]. This process in the Old World gained momentum during the classical period and it is argued that both maritime and terrestrial trade networks played crucial roles in the spread of cats [3]. The transmission of the domestic cat from Egypt to Europe also occurred through various routes. The earliest example of such spread was found via evidence in the form of 5th-4th century BC Greek art works in the southern region of the Italian peninsula [4].

In Turkey (ancient Anatolia), domestic cats are known to have existed at least from the Roman period [5]. Roman poet Ovid's reference to the sanctity of the Egyptian cat can be attributed to the evidence that Romans were familiar with domestic cats from 100 BC [6]. Yet, the term "domestic cat" or "cat" was rarely mentioned in Roman literary texts, perhaps because they were described as "pest controllers" for killing rats and mice in households [5]. Cats' domestication process has led them to play an important sanitary role in human settlements [1]. Simultaneously, the role and the importance of the cat in household probably did not significantly increase before the transition from the classical to medieval period [7]. Arguably because of this reason, the domestic cat was not mentioned in Roman literary sources [8], including the great agricultural lore Geoponica (6th century $\mathrm{AD}$ ), or in the works of the prominent Roman agriculture writer Columella (1st century AD) [5]. However, although such negligence was present in terms of highlighting the contributions of house cats in human society, this perhaps did not prevent them from being a favorite pet animal.

The domestication of cats marked the beginning of the acceptance of cats as pet animals [1]. As pets, they gained the scope to enter the inner sphere of the human world. Among medieval societies, cats were generally seen as a symbol of possessing luxurious goods-in addition to emphasizing the owners' desire to express their high social status and exhibit their material assets - the way cats were kept was seen as an identity defining factor of their owners [9]. This was a very different situation than keeping a cat as a rodent controller in the household. The task of pest control was at the forefront of the cat domestication process, which was associated with a commensal relationship between humans and cats [10]. Before the widespread increase in the perceived value of cats, both the Greeks and Romans preferred snakes and weasels for killing rodents and pest control [11]. However, given the fact that they are cleaner animals for the tasks-as well as good companions at home-instead of snakes and weasels, domestic cats started to be preferred throughout the 2nd-5th century AD [6].

According to the Roman author Pliny the Elder [12], domestic cats replaced mustelids in the early Christian era [10]. It is also suggested by ancient writers, however, that the terms weasels and cats were used interchangeably, without making any distinction [13]. It is argued that the lack of popularity resulted in the domestic cat having not yet received a standard name at that point in time [14]. Nevertheless, from 200 AD the words "catus" and "catta" were commonly used for describing the cats [5].

The only thing that cannot be determined from the cat remains found in Roman archaeological sites was the actual status of these animals and the question of whether they were used as "pest controllers" or "pets" at these settlements [15]. Zooarchaeological evidence has indicated the existence of human-cat relationships for thousands of years [16-18]. Yet, due to the scarcity of cat remains in archaeological records, current hypotheses for early cat domestication are based on only a few zooarchaeological case studies [3]. The rarity of cat remains in the Graeco-Roman archaeological context [19] also restricts our knowledge about the role and functions of cats, as well as their status of being domestic or wild cats. It appears that there were no early finds of domestic cats in Anatolia [5]. Considering the small number of cat remains obtained from only a few Roman sites, including Didim [20], Pergamon [21], Lidar Höyük [22], Pessinus [23], Troy [24] and Sagalassos [5], it can be argued that domestic cats were brought to Anatolia at least during the Roman period [5]. 
On the other hand, although some argue the dominance of the negative image of cats in Byzantine records [25], it should be questioned whether this existed in the early Byzantine time. Besides of being pet animals, cats were also used in the Byzantine world to keep rodents under control [26]. Despite the scarcity of cat remains at the Roman sites in Anatolia, a very rich assemblage of cat remains from the Yenikapı Metro and Marmaray excavation demonstrated that cats played a remarkable role in the life of the Byzantine capital Constantinople [27-30]. The Yenikapı cat assemblage belongs to the Early Byzantine (4th-7th century AD) to Late Byzantine period (15th century AD) [28], and when their quantities are compared, it appears that to date, no other Byzantine site has yielded such a large assemblage of cat remains. The Yenikapı remains also showed that, besides of being pets, cats continued to play a significant part in the urban life of Constantinople. On the other hand, the fact that cats were among the favorite animals of the Byzantine empress Zoë (1028-1050) [25], also demonstrates the higher status of cats in Byzantine society. In this regard, the Balatlar cat presents the most significant direct archaeological evidence of a cat-human bond found at any Byzantine site so far.

\section{Materials and Methods}

\subsection{Achaeological Site}

The Balatlar Church complex lies in the ancient Paphlagonia region and at the heart of the present provincial city of Sinop, at $42^{\circ} 01^{\prime} 34^{\prime \prime}$ north latitude and $35^{\circ} 09^{\prime} 25^{\prime \prime}$ east longitude, where the Boztepe peninsula connects to the mainland [31] on the northernmost edge of the Turkish Black Sea coast (Figure 1). Archaeological excavations at this building complex began in 2010 under the direction of Gülgün Köroğlu and the site gained its official name as the "Balatlar Church". It was found that the original purpose of this building complex was as an imperial bath during the Late Roman period, later it was converted into a church and was spread over a wider area [31]. The complex is comprised of building remains of different architectural styles. Although known as the Byzantine "church" among the public statements and in archaeological studies, the site revealed several archaeological layers, including the evidence of occupation during the Late Hellenistic, Roman, Byzantine, Seljuk and Ottoman periods [32,33]. The site was an active royal bath complex during 3 rd-4th century AD [32]. Following the acceptance of Christianity and its affirmation as the official estate religion, the caldarium (heat section) of the building was converted into a church during the mid-4th or 5th century $\mathrm{AD}[32,34]$. In the 7th century, a small chapel with a single nave was added to its south cross arm. From the 12th or 13th century until the first quarter of the 20th century, the northeast corner room of the tepidarium (tepidity) of the bathhouse (Room No. I) continued to be used as a church (Figures 2 and 3).

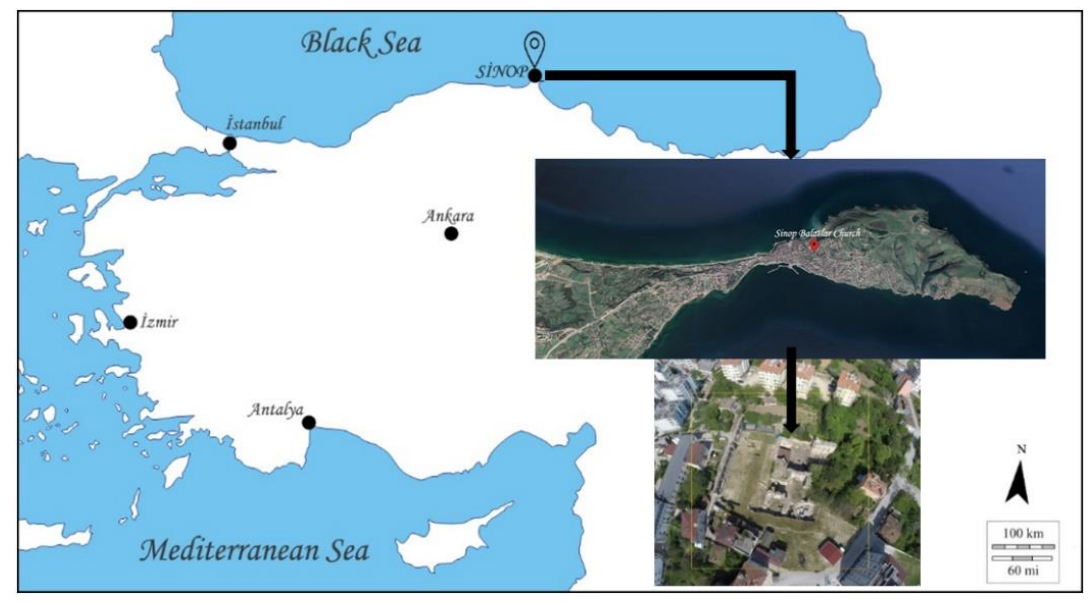

Figure 1. Location and overview plain of the Balatlar Group Complex in Sinop (Base \& above: free maps, "http: / /www.d-maps.com $\backslash \mathrm{T} 1 \backslash$ textquotedblright \& Google Earth; below: Balatlar Excavation Archive). 


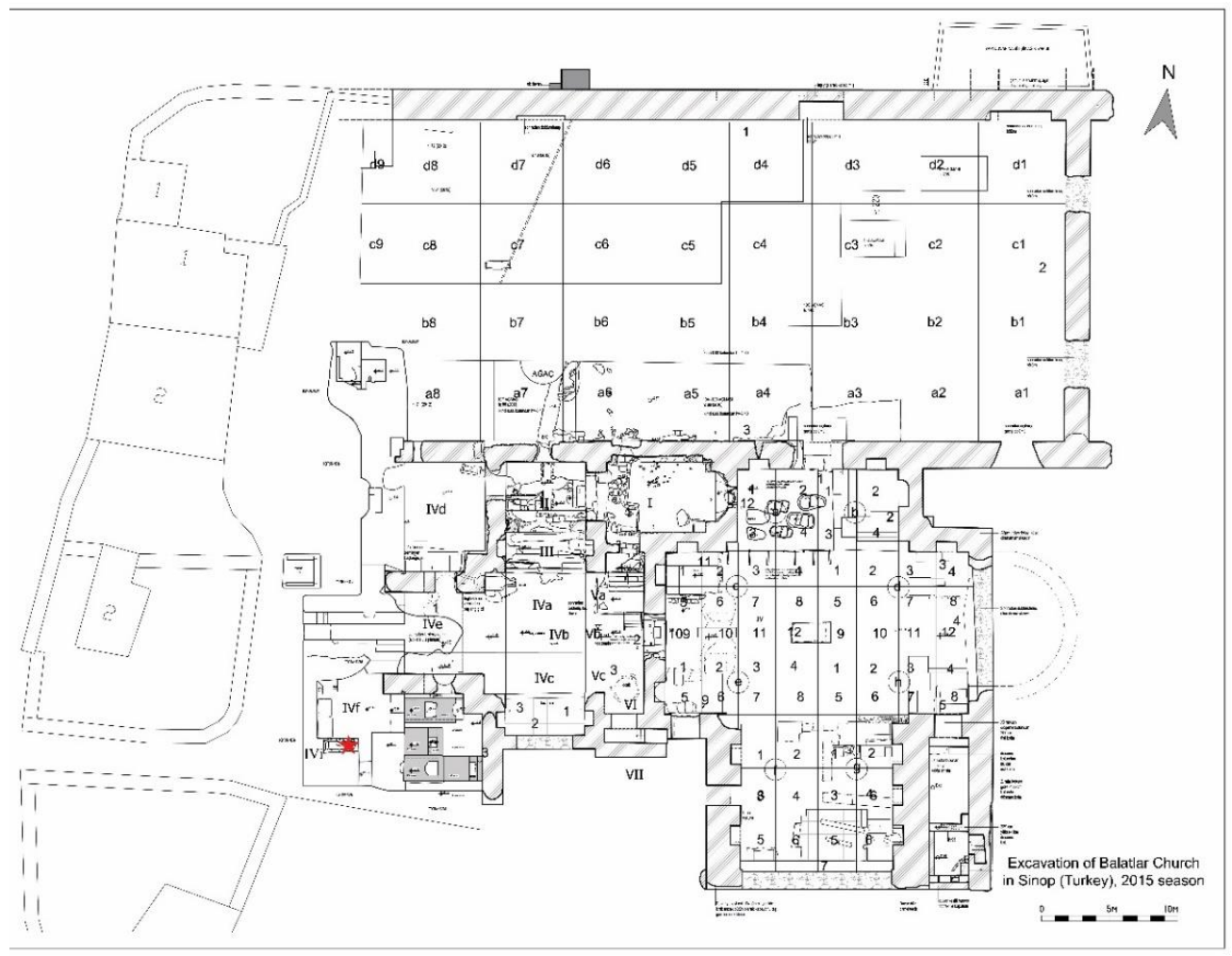

Figure 2. Areas under 2015 excavation at the Balatlar Church complex: the red star indicates "2015-Grave 14" burial chamber.

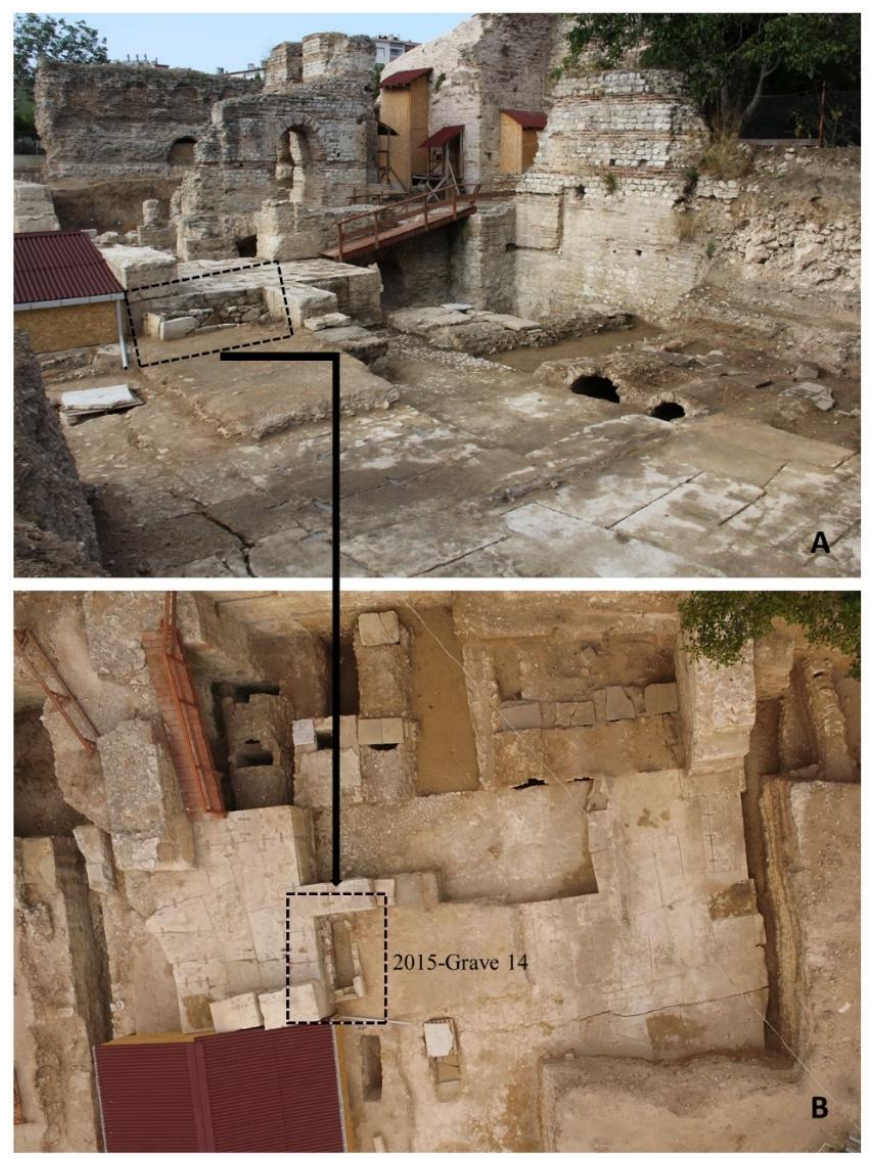

Figure 3. Close view of the "2015-Grave-14" burial chamber at the Balatlar Church complex. 
The floor of the church, and especially its surroundings, were used as a cemetery [34], and many of the burials belonging to its early period were unearthed in recent excavations [32]. One of these burials was a burial chamber from "Area IVi" where the cat was buried with a human individual (Figure 4). To construct a comparative dating of this "2015-burial chamber 14" of Area IVi, the burial remains of "Area IVf" to the east were used as a benchmark. The burial chamber of IVf was dated back to between the end of the 6th century AD and the first half of the 7th century AD. Located in the same cultural layer and adjacent to the burial chamber of IVf, it has been suggested that the burial chamber of IVi also belonged to the same period. Beyond being a pet animal with burial status, the cat skeleton of this grave was examined with consideration of an indicator for human-pet animal relationships in the Byzantine world.

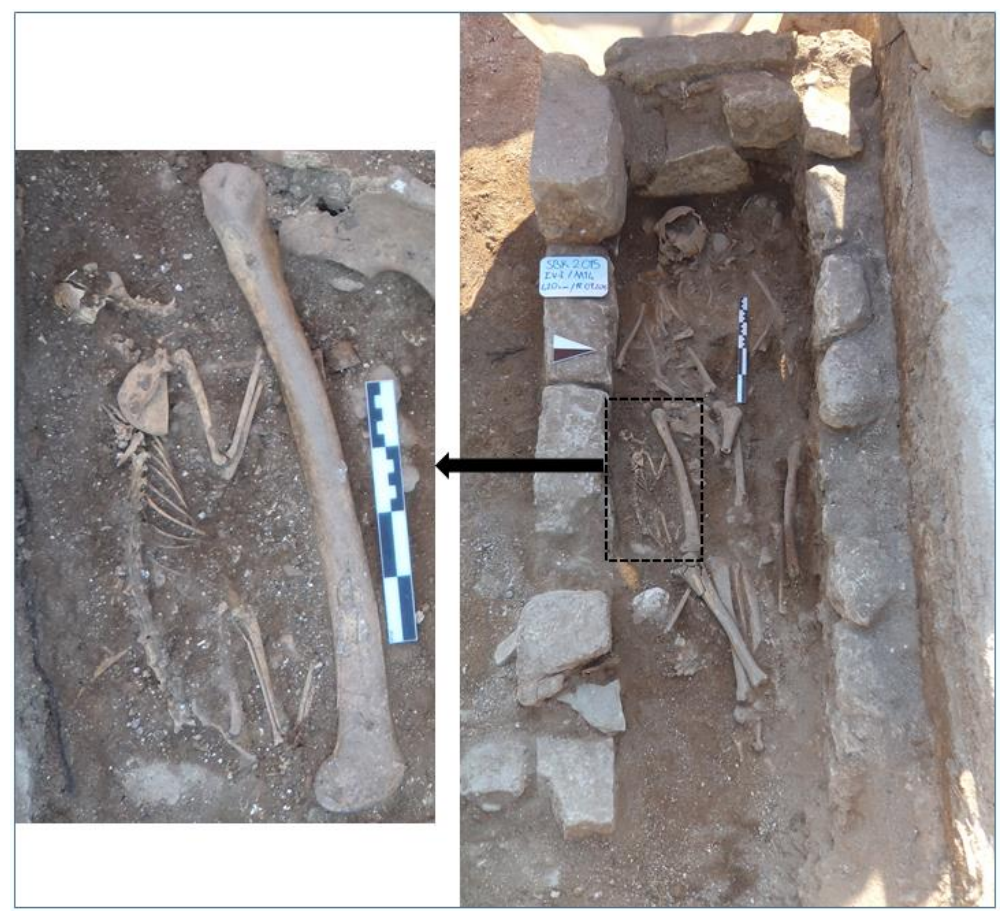

Figure 4. In situ view of the cat skeleton (Balatlar cat) at the "2015-Grave 14" chamber.

\subsection{Zooarchaeological Evidence}

A cat skeleton, associated with a human skeleton in the "2015-grave 14" from Area IVi of the Balatlar Church complex, was examined in this study. The cat was carefully placed next to the right femur the human individual, who was the last person buried in the grave chamber. The cat and human skeleton were observed to be synchronous, given that they were the only ones placed in the same depositional layer, which meant they were separated from lower human remains by a distinct soil layer. The sex of the human individual remains unidentified, but is expected to be determined by future studies. The skull of the cat was found to be fragmented, possibly due to the collapse of the chamber. Except the fragmented skull, osteometric measurements were taken from the mandiblae, scapula, humerus, radius, ulna, coxae, femur, tibia, fibula, talus, calcaneus, metapodiums, atlas, axis and sacrum of the skeleton.

\subsection{Calculation of Domestic Status and Morphology}

Basic standards of the skeletal measurements were followed from von den Driesch (1976) [35], von den Driesch and Boessneck (1983) [36], Kratochvil (1973, 1976) [37,38], Teichert (1978) [39] and Guintard and Arnaud (2003) [40]. In this way, it was possible to compare the Balatlar cat with cat measurements found in different periods and localities, but close to each other. In addition to these archaeological examples, the cat was also 
compared with the measurements of an Angora cat in our laboratory, in order to make a comparison with a modern sample. The comparison and evaluation of the measurements revealed possible morphological differences of the Balatlar cat from those presented in the wild cat (Felis silvestris) and modern domestic cat (Felis catus).

A Z-score calculation was further performed to compare raw morphometric data obtained from the Balatlar cat skeleton with those of the domestic and wild samples. Thus, with the help of the obtained $\mathrm{Z}$ score, it was possible to determine which direction (positive or negative) and by how many units the Balatlar cat deviated from the average mean of the domestic and wild cat data.

\subsection{Osteometric Measurements}

All morphometric measurements were taken using an electronic slide-caliper and were repeated three times to estimate the mean value. The detalied description of this prcedure is presented in Table 1. The results were compared with the accessible literature and discussed.

Table 1. Description of the morphometric measurements used in the study.

\begin{tabular}{|c|c|c|}
\hline \multicolumn{3}{|c|}{ Mandibula } \\
\hline No. & Measurement & Reference \\
\hline 1 & Total length: length from the condyle process-infradentale & $\begin{array}{l}\text { von den Driesch, 1976: No.1 [35]; von den Driesch and Boessneck, } \\
\text { 1983: No.1 [36]; Kratochvil, 1973: No.2 [37]; Teichert, 1978: No.2 [39]; } \\
\text { Guintard and Arnaud, 2003: No.1 [40] }\end{array}$ \\
\hline 2 & $\begin{array}{l}\text { Length from the indentation between the condyle process and the } \\
\text { angular process-infradentale }\end{array}$ & $\begin{array}{l}\text { von den Driesch, 1976: No.2 [35]; von den Driesch and Boessneck, } \\
\text { 1983: No.3 [36]; Kratochvil, 1973: No.4 [37]; Teichert, 1978: No.4 [39]; } \\
\text { Guintard and Arnaud, 2003: No.2 [40] }\end{array}$ \\
\hline 3 & The condyle process-aboral border of the canine alveolus & $\begin{array}{l}\text { von den Driesch, 1976: No.3 [35]; von den Driesch and Boessneck, } \\
\text { 1983: No.5 [36]; Kratochvil, 1973: No.5 [37]; Teichert, 1978: No.5 [39]; } \\
\text { Guintard and Arnaud, 2003: No.3 [40] }\end{array}$ \\
\hline 4 & $\begin{array}{l}\text { Length from the indentation between the condyle process and the } \\
\text { angular process-aboral border of the canine alveolus }\end{array}$ & $\begin{array}{l}\text { von den Driesch, 1976:No.4 [35]; Kratochvil, 1973: No.6 [37]; Teichert, } \\
\text { 1978: No.6 [39]; Guintard and Arnaud, 2003: No.4 [40] } \\
\text { von den Driesch and Boessneck, 1983: No.2 [36]; Kratochvil, 1973: }\end{array}$ \\
\hline 5 & Length from the angular process-infradentale & $\begin{array}{l}\text { No.3 [37]; Teichert, 1978: No.3 [39]; Guintard and Arnaud, 2003: } \\
\text { No.11 [40] }\end{array}$ \\
\hline 6 & Length from the condyle process-oral border of the canine alveolus & von den Driesch and Boessneck, 1983: No.4 [36] \\
\hline 7 & Length from the coronoid process-infradentale & Kratochvil, 1973: No.1 [37]; Teichert, 1978: No.4 [39] \\
\hline 8 & $\begin{array}{l}\text { Length from the angular process-aboral border of the canine } \\
\text { alveolus }\end{array}$ & Kratochvil, 1973: No.7 [37]; Teichert, 1978: No.7 [39] \\
\hline 9 & Length of the cheektooth row, P3-M1, measured along the alveoli & $\begin{array}{l}\text { von den Driesch, 1976:No.5 [35]; von den Driesch and Boessneck, } \\
\text { 1983: No.9 [36]; Kratochvil, 1973: No.9 [37]; Teichert, 1978: No.9 [39]; } \\
\text { Guintard and Arnaud, 2003: No.5 [40] } \\
\text { von den Driesch, 1976: No.6-length [35]; von den Driesch and }\end{array}$ \\
\hline 10 & Length of the carnassial (M1), measured at the cingulum & $\begin{array}{l}\text { Boessneck, 1983: No.10-length [36]; Kratochvil, 1973: No.11 [37]; } \\
\text { Teichert, 1978: No.11 [39]; Guintard and Arnaud, 2003: No.6 [40] } \\
\text { von den Driesch, 1976:No.6-breadth [35]; von den Driesch and }\end{array}$ \\
\hline 11 & Breadth of the carnassial (M1), measured at the cingulum & $\begin{array}{l}\text { Boessneck, 1983: No.10-breadth [36]; Kratochvil, 1973: No.12 [37]; } \\
\text { Teichert, 1978: No.12 [39]; Guintard and Arnaud, 2003: No.6a [40] }\end{array}$ \\
\hline 12 & Length of the carnassial alveolus & $\begin{array}{l}\text { von den Driesch, 1976:No.7 [35]; Guintard and Arnaud, 2003: No.7 } \\
\text { [40] }\end{array}$ \\
\hline 13 & Length of the premolar row, $\mathrm{P} 3-\mathrm{P} 4$, measured along the alveoli & Kratochvil, 1973: No.10 [37]; Teichert, 1978: No.10 [39] \\
\hline 14 & $\begin{array}{l}\text { Height of the vertical ramus (Ramus mandibulae): basal point of } \\
\text { the angular process-Coronion }\end{array}$ & $\begin{array}{l}\text { von den Driesch, 1976:No.8 [35]; von den Driesch and Boessneck, } \\
\text { 1983: No.11 [36]; Kratochvil, 1973: No.15 [37]; Teichert, 1978: No.15 } \\
\text { [39]; Guintard and Arnaud, 2003: No.8 [40] }\end{array}$ \\
\hline 15 & Height of the mandible behind M1, measured on the buccal side & $\begin{array}{l}\text { von den Driesch, 1976:No.9 [35]; von den Driesch and Boessneck, } \\
\text { 1983: No.12 [36]; Kratochvil, 1973: No.14 [37]; Teichert, 1978: No.14 } \\
\text { [39]; Guintard and Arnaud, 2003: No.9 [40] }\end{array}$ \\
\hline 16 & Height of the mandible between P3-P4, measured on the buccal side & Kratochvil, 1973: No.13 [37]; Teichert, 1978: No.13 [39] \\
\hline 17 & Heigth of the mandible in front of $\mathrm{P} 3$, measured on the buccal side & $\begin{array}{l}\text { von den Driesch, 1976:No.10 [35]; Guintard and Arnaud, 2003: No.10 } \\
\text { [40] }\end{array}$ \\
\hline 18 & $\begin{array}{l}\text { Length of the C1-M1: length of the aboral border of the canine } \\
\text { alveolus-the aboral border of the M1 alveolus }\end{array}$ & Kratochvil, 1973: No.8 [37]; Teichert, 1978: No.8 [39] \\
\hline 19 & Length of the aboral border of the M1 alveolus-infradentale & Guintard and Arnaud, 2003: No.12 [40] \\
\hline
\end{tabular}


Table 1. Cont.

\begin{tabular}{|c|c|c|}
\hline \multicolumn{3}{|c|}{ Scapula } \\
\hline No & Measurement & Reference \\
\hline 1 & Height along the spine & $\begin{array}{l}\text { von den Driesch, 1976: HS [35]; von den Driesch and Boessneck, 1983: } \\
\text { HS [36]; Kratochvil, 1976: No.11 [38] }\end{array}$ \\
\hline 2 & $\begin{array}{l}\text { Diagonal height: From the most distal point of the scapula to the } \\
\text { thoracic angle }\end{array}$ & $\begin{array}{l}\text { von den Driesch, 1976: DHA [35]; von den Driesch and Boessneck, } \\
\text { 1983: DHA [36] }\end{array}$ \\
\hline 3 & Greatest dorsal length & von den Driesch, 1976: Ld [35]; Kratochvil, 1976: No.12 [38] \\
\hline 4 & Smallest length of the collum scapulae & $\begin{array}{l}\text { von den Driesch, 1976: SLC [35]; von den Driesch and Boessneck, } \\
\text { 1983: SLC [36]; Kratochvil, 1976: No.13 [38] }\end{array}$ \\
\hline 5 & Greatest length of the processus articularis (glenoid) & $\begin{array}{l}\text { von den Driesch, 1976: GLP [35]; von den Driesch and Boessneck, } \\
\text { 1983: GLP [36]; Kratochvil, 1976: No.14 [38] }\end{array}$ \\
\hline 6 & Length of the glenoid cavity & $\begin{array}{l}\text { von den Driesch, 1976: LG [35]; von den Driesch and Boessneck, 1983: } \\
\text { LG [36]; Kratochvil, 1976: No.15 [38] }\end{array}$ \\
\hline 7 & Breadth of the glenoid cavity & $\begin{array}{l}\text { von den Driesch, 1976: BG [35]; von den Driesch and Boessneck, 1983: } \\
\text { BG [36]; Kratochvil, 1976: No.16 [38] }\end{array}$ \\
\hline 8 & Height in the area of the spina scapulae & Kratochvil, 1976: No.10 [38] \\
\hline
\end{tabular}

\begin{tabular}{|c|c|c|}
\hline \multicolumn{3}{|c|}{ Humerus } \\
\hline No & Measurement & Reference \\
\hline 1 & Greatest length & $\begin{array}{l}\text { von den Driesch, 1976: GL [35]; von den Driesch and Boessneck, 1983: } \\
\text { GL [36]; Kratochvil, 1976: No.17 [38] }\end{array}$ \\
\hline 2 & Greatest length from caput & $\begin{array}{l}\text { von den Driesch, 1976: GLC [35]; von den Driesch and Boessneck, } \\
\text { 1983: GLC [36] }\end{array}$ \\
\hline 3 & Greatest breadth of the proximal end & $\begin{array}{l}\text { von den Driesch, 1976: Bp [35]; von den Driesch and Boessneck, 1983: } \\
\text { Bp [36] }\end{array}$ \\
\hline 4 & Depth of the proximal end & $\begin{array}{l}\text { von den Driesch, 1976: Dp [35]; von den Driesch and Boessneck, 1983: } \\
\text { Dp [36]; Kratochvil, 1976: No.18 [38] }\end{array}$ \\
\hline 5 & Smallest breadth of the diaphysis & $\begin{array}{l}\text { von den Driesch, 1976: SD [35]; von den Driesch and Boessneck, 1983: } \\
\text { SD [36]; Kratochvil, 1976: No.19 [38] }\end{array}$ \\
\hline 6 & Breadth of the distal end & $\begin{array}{l}\text { von den Driesch, 1976: Bd [35]; von den Driesch and Boessneck, 1983: } \\
\text { Bd [36]; Kratochvil, 1976: No.20 [38] }\end{array}$ \\
\hline
\end{tabular}

\begin{tabular}{|c|c|c|}
\hline \multicolumn{3}{|c|}{ Radius } \\
\hline No & Measurement & Reference \\
\hline 1 & Greatest length & $\begin{array}{l}\text { von den Driesch, 1976: GL [35]; von den Driesch and Boessneck, 1983: } \\
\text { GL [36]; Kratochvil, 1976: No.21 [38] }\end{array}$ \\
\hline 2 & Greatest breadth of the proximal end & $\begin{array}{l}\text { von den Driesch, 1976: Bp [35]; von den Driesch and Boessneck, 1983: } \\
\text { Bp [36]; Kratochvil, 1976: No.22 [38] }\end{array}$ \\
\hline 3 & Depth of the proximal end & Kratochvil, 1976: No.23 [38] \\
\hline 4 & Smallest breadth of the diaphysis & $\begin{array}{l}\text { von den Driesch, 1976: SD [35]; von den Driesch and Boessneck, 1983: } \\
\text { SD [36]; Kratochvil, 1976: No.24 [38] }\end{array}$ \\
\hline 5 & Greatest breadth of the distal end & $\begin{array}{l}\text { von den Driesch, 1976: Bd [35]; von den Driesch and Boessneck, 1983: } \\
\text { Bd [36]; Kratochvil, 1976: No.25 [38] }\end{array}$ \\
\hline \multicolumn{3}{|c|}{ Ulna } \\
\hline No & Measurement & Reference \\
\hline 1 & Greatest length & $\begin{array}{l}\text { von den Driesch, 1976: GL [35]; von den Driesch and Boessneck, 1983: } \\
\text { GL [36]; Kratochvil, 1976: No.26 [38] }\end{array}$ \\
\hline 2 & Length of the olecranon & von den Driesch, 1976: LO [35] \\
\hline 3 & Depth across the processus anconeus & $\begin{array}{l}\text { von den Driesch, 1976: DPA [35]; von den Driesch and Boessneck, } \\
\text { 1983: DPA [36]; Kratochvil, 1976: No.27 [38] }\end{array}$ \\
\hline 4 & Smallest depth of the olecranon & $\begin{array}{l}\text { von den Driesch, 1976: SDO [35]; von den Driesch and Boessneck, } \\
\text { 1983: SDO [36] }\end{array}$ \\
\hline 5 & Breadth across the coronoid process & $\begin{array}{l}\text { von den Driesch, 1976: BPC [35]; von den Driesch and Boessneck, } \\
\text { 1983: BPC [36]; Kratochvil, 1976: No.28 [38] }\end{array}$ \\
\hline \multicolumn{3}{|c|}{ Ossa coxae } \\
\hline No & Measurement & Reference \\
\hline 1 & Greatest length of one half & $\begin{array}{l}\text { von den Driesch, 1976: GL [35]; von den Driesch and Boessneck, 1983: } \\
\text { GL [36]; Kratochvil, 1976: No.39 [38] }\end{array}$ \\
\hline 2 & Greatest length of acetabulum including the lip & von den Driesch, 1976: LA [35] \\
\hline 3 & Greatest length of acetabulum on the rim & $\begin{array}{l}\text { von den Driesch, 1976: LAR [35]; von den Driesch and Boessneck, } \\
\text { 1983: LAR [36]; Kratochvil, 1976: No.43 [38] }\end{array}$ \\
\hline 4 & Length of the symphysis & von den Driesch, 1976: LS [35]; Kratochvil, 1976: No.42 [38] \\
\hline 5 & Smallest height of the shaft of ilium & von den Driesch, 1976: SH [35]; Kratochvil, 1976: No.45 [38] \\
\hline 6 & Smallest breadth of the shaft of ilium & von den Driesch, 1976: SB [35]; Kratochvil, 1976: No.46 [38] \\
\hline 7 & Inner length of the foramen obturatum & von den Driesch, 1976: Lfo [35] \\
\hline
\end{tabular}


Table 1. Cont.

\begin{tabular}{|c|c|c|}
\hline \multicolumn{3}{|c|}{ Femur } \\
\hline No & Measurement & Reference \\
\hline 1 & Greatest length & $\begin{array}{l}\text { von den Driesch, 1976: GL [35]; von den Driesch and Boessneck, 1983: } \\
\text { GL [36]; Kratochvil, 1976: No.51 [38] }\end{array}$ \\
\hline 2 & Greatest breadth of the proximal length & $\begin{array}{l}\text { von den Driesch, 1976: Bp [35]; von den Driesch and Boessneck, 1983: } \\
\text { Bp [36]; Kratochvil, 1976: No.52 [38] }\end{array}$ \\
\hline 3 & Greatest depth of the caput femoris & von den Driesch, 1976: DC [35]; Kratochvil, 1976: No.53 [38] \\
\hline 4 & Smallest breadth of the diaphysis & $\begin{array}{l}\text { von den Driesch, 1976: SD [35]; von den Driesch and Boessneck, 1983: } \\
\text { SD [36]; Kratochvil, 1976: No.54 [38] }\end{array}$ \\
\hline 5 & Greatest breadth of the distal end & $\begin{array}{l}\text { von den Driesch, 1976: Bd [35]; von den Driesch and Boessneck, 1983: } \\
\text { Bd [36]; Kratochvil, 1976: No.55 [38] }\end{array}$ \\
\hline \multicolumn{3}{|c|}{ Tibia } \\
\hline No & Measurement & Reference \\
\hline 1 & Greatest length & $\begin{array}{l}\text { von den Driesch, 1976: GL [35]; von den Driesch and Boessneck, 1983: } \\
\text { GL [36]; Kratochvil, 1976: No.58 [38] }\end{array}$ \\
\hline 2 & Greatest breadth of the proximal end & $\begin{array}{l}\text { von den Driesch, 1976: Bp [35]; von den Driesch and Boessneck, 1983: } \\
\text { Bp [36]; Kratochvil, 1976: No.59 [38] }\end{array}$ \\
\hline 3 & Smallest breadth of the diaphysis & $\begin{array}{l}\text { von den Driesch, 1976: SD [35]; von den Driesch and Boessneck, 1983: } \\
\text { SD [36]; Kratochvil, 1976: No.60 [38] }\end{array}$ \\
\hline 4 & Greatest breadth of the distal end & $\begin{array}{l}\text { von den Driesch, 1976: Bd [35]; von den Driesch and Boessneck, 1983: } \\
\text { Bd [36] }\end{array}$ \\
\hline 5 & Greatest depth of the distal end & von den Driesch, 1976: Dd [35]; Kratochvil, 1976: No.61 [38] \\
\hline \multicolumn{3}{|c|}{ Fibula } \\
\hline No & Measurement & Reference \\
\hline 1 & Greatest length & $\begin{array}{l}\text { von den Driesch, 1976: GL [35]; von den Driesch and Boessneck, 1983: } \\
\text { GL [36]; Kratochvil, 1976: No.62 [38] }\end{array}$ \\
\hline \multicolumn{3}{|c|}{ Talus } \\
\hline No & Measurement & Reference \\
\hline 1 & Greatest length & von den Driesch, 1976: GL [35]; Kratochvil, 1976: No.63 [38] \\
\hline \multicolumn{3}{|c|}{ Calcaneus } \\
\hline No & Measurement & Reference \\
\hline 1 & Greatest length & $\begin{array}{l}\text { von den Driesch, 1976: GL [35]; von den Driesch and Boessneck, 1983: } \\
\text { GL [36]; Kratochvil, 1976: No.64 [38] }\end{array}$ \\
\hline 2 & Greatest breadth & $\begin{array}{l}\text { von den Driesch, 1976: GB [35]; von den Driesch and Boessneck, 1983: } \\
\text { GB [36]; Kratochvil, 1976: No.65 [38] }\end{array}$ \\
\hline \multicolumn{3}{|c|}{ Metapodials } \\
\hline No & Measurement & Reference \\
\hline 1 & Greatest length & $\begin{array}{l}\text { von den Driesch, 1976: GL [35]; von den Driesch and Boessneck, 1983: } \\
\text { GL [36]; Kratochvil, 1976: No.29, 30, 32, 34, 36, 66, 68, 70, } 72 \text { [38] }\end{array}$ \\
\hline 2 & Greatest breadth of the distal end & $\begin{array}{l}\text { von den Driesch, 1976: Bd [35]; von den Driesch and Boessneck, 1983: } \\
\text { Bd [36]; Kratochvil, 1976: No.31, 33, 35, 67, 69, 71, } 73 \text { [38] }\end{array}$ \\
\hline \multicolumn{3}{|c|}{ Atlas } \\
\hline No & Measurement & Reference \\
\hline 1 & Greatest breadth over the wings & $\begin{array}{l}\text { von den Driesch, 1976: GB [35]; von den Driesch and Boessneck, 1983: } \\
\text { GB [36]; Kratochvil, 1976: No.4 [38] }\end{array}$ \\
\hline 2 & Greatest length & $\begin{array}{l}\text { von den Driesch, 1976: GL [35]; von den Driesch and Boessneck, 1983: } \\
\text { GL [36]; Kratochvil, 1976: No.1 [38] }\end{array}$ \\
\hline 3 & Greatest breadth of the facies articularis cranialis & $\begin{array}{l}\text { von den Driesch, 1976: BFcr [35]; von den Driesch and Boessneck, } \\
\text { 1983: BFcr [36]; Kratochvil, 1976: No.2 [38] }\end{array}$ \\
\hline 4 & Greatest breadth of the facies articularis caudalis & $\begin{array}{l}\text { von den Driesch, 1976: BFcd [35]; von den Driesch and Boessneck, } \\
\text { 1983: BFcd [36]; Kratochvil, 1976: No.3 [38] }\end{array}$ \\
\hline 5 & $\begin{array}{l}\text { Greatest length from the facies articularis cranialis to the facies } \\
\text { articularis caudalis }\end{array}$ & $\begin{array}{l}\text { von den Driesch, 1976: GLF [35]; von den Driesch and Boessneck, } \\
\text { 1983: GLF [36] }\end{array}$ \\
\hline 6 & Length of the arcus dorsalis & von den Driesch, 1976: Lad [35] \\
\hline 7 & Height & von den Driesch, 1976: H [35] \\
\hline
\end{tabular}


Table 1. Cont.

\begin{tabular}{|c|c|c|}
\hline \multicolumn{3}{|c|}{ Axis } \\
\hline No & Measurement & Reference \\
\hline 1 & Greatest length in the region of the corpus including dens & $\begin{array}{l}\text { von den Driesch, 1976: LCDe [35]; von den Driesch and Boessneck, } \\
\text { 1983: LCDe [36]; Kratochvil, 1976: No.5 [38] }\end{array}$ \\
\hline 2 & $\begin{array}{l}\text { Greatest length of the arch including the processus articulares } \\
\text { caudales }\end{array}$ & $\begin{array}{l}\text { von den Driesch, 1976: LAPa [35]; von den Driesch and Boessneck, } \\
\text { 1983: LAPa [36] }\end{array}$ \\
\hline 3 & Greatest breadth of the facies articularis cranialis & $\begin{array}{l}\text { von den Driesch, 1976: BFcr [35]; von den Driesch and Boessneck, } \\
\text { 1983: BFcr [36]; Kratochvil, 1976: No.6 [38] }\end{array}$ \\
\hline 4 & Greatest breadth across the processus articulares caudales & $\begin{array}{l}\text { von den Driesch, 1976: BPacd [35]; von den Driesch and Boessneck, } \\
\text { 1983: BPacd [36] }\end{array}$ \\
\hline 5 & Greatest breadth across the processus transversi & von den Driesch, 1976: BPtr [35] \\
\hline 6 & Smallest breadth of the vertebra & $\begin{array}{l}\text { von den Driesch, 1976: SBV [35]; von den Driesch and Boessneck, } \\
\text { 1983: SBV [36]; Kratochvil, 1976: No.7 [38] }\end{array}$ \\
\hline 7 & Greatest breadth of the facies articularis caudalis & von den Driesch, 1976: BFcd [35] \\
\hline 8 & Greatest height & $\begin{array}{l}\text { von den Driesch, 1976: H [35]; von den Driesch and Boessneck, 1983: } \\
\text { H [36]; Kratochvil, 1976: No.8 [38] }\end{array}$ \\
\hline 9 & Height of the processus spinosus cranially & Kratochvil, 1976: No.9 [38] \\
\hline \multicolumn{3}{|c|}{ Sacrum } \\
\hline No & Measurement & Reference \\
\hline 1 & Greatest length on the ventral side & $\begin{array}{l}\text { von den Driesch, 1976: GL [35]; von den Driesch and Boessneck, 1983: } \\
\text { GL [36] }\end{array}$ \\
\hline 2 & Physiological length & von den Driesch, 1976: PL [35]; Kratochvil, 1976: No.37 [38] \\
\hline 3 & Greatest breadth across the wings & $\begin{array}{l}\text { von den Driesch, 1976: GB [35]; von den Driesch and Boessneck, 1983: } \\
\text { GB [36]; Kratochvil, 1976: No.38 [38] }\end{array}$ \\
\hline 4 & Greatest breadth of the facies articularis cranialis & von den Driesch, 1976: BFcr [35] \\
\hline 5 & Greatest height of the facies articularis cranialis & von den Driesch, 1976: HFcr [35] \\
\hline
\end{tabular}

In pet animals, particular index calculations are made using morphometric measurements of the long bones of the front and hind legs. One of these indices, is the slenderness index which is accepted as an indicator of the strength of a particular animal individual and is used to classify whether the front and hind limbs of the individual are thin or thick [41-43]. In this study, index calculations were made using measurements of the humerus, radius, femur and tibia of the cat. In this way, the visual morphology of the Balatlar cat was evaluated by comparing these data with the cat indices obtained from different archaeological sites and modern samples.

Calculated indices:

Humerus index $=\mathrm{SD}^{*} 100 / \mathrm{GL}$.

Radius index $=\mathrm{SD}^{*} 100 / \mathrm{GL}$.

Femur index $=\mathrm{SD}^{*} 100 / \mathrm{GL}$.

Tibia index $=S D^{*} 100 / G L$.

\subsection{Animal Age Estimation}

On the basis of time indices for the epiphyseal fusion of the long bones, the animal age was estimated. The dentition status was not evaluated. The strong fragmentation of the cranial skeleton and teeth did not allow for more advanced studies. The number of alveoli suggested that the dental formula for both dental arches was normal and all teeth had erupted.

\subsection{Animal Sex Estimation}

Animal sex was estimated on the basis of the existence of the os penis. The presence of this bony structure is typical for all Carnivora.

\section{Results}

In the second intermediate period of the 2015 excavation season at the Balatlar Church complex, a grave was unearthed from the end of the bosage surface stone blocks of Trench IVi. The grave was placed in the east direction, covered with large block stones, and associated with an earlier occupational period of the site (Figure 3). When the grave 
was cleaned and opened, a human skeleton was found lying with the head towards the west and feet towards the east. The cat was placed next to the right femur of this human individual, who was the last person buried in the grave chamber (Figure 4). Although there were multiple burials in the chamber, it was observed that the cat and human skeleton were placed in the upper-most layer, being completely separated from the lower burials by a distinct soil layer.

The cat skeleton, laid on its left side, was also carefully placed in the east-west direction following the human skeleton. Considering the times of its epiphyseal closure (fusion) of different skeletal parts, it was found that the cat was a young female individual (Table 2). In particular, the absence of the os penis and the fact that the long bones were not large and heavy, but smaller and delicate, directed the determination of the individual to be a young female cat. Both the general morphology of the bones and morphometric examination of the skeletal remains indicated the remains to belong to a domestic cat. Moreover, considering the fact that it was carefully placed in a human grave, in proximity to the human individual, the cat appeared to be a pet animal.

Table 2. Calculated age of the Balatlar cat using the time index of epiphyseal closure [44].

\begin{tabular}{|c|c|c|c|c|}
\hline \multirow{2}{*}{ Bone } & \multirow{2}{*}{ Epiphyseal Plate Closure } & \multicolumn{2}{|c|}{ Smith 1969} & \multirow{2}{*}{$\begin{array}{c}\text { Balatlar Cat } \\
\text { Fused/unfused }\end{array}$} \\
\hline & & DAYS & MONTH & \\
\hline Humerus & Medial condyle & 98 & 3.3 & Fused \\
\hline Humerus & Lateral condyle & 98 & 3.3 & Fused \\
\hline Scapula & Tuber\&corocoid proccess & 112 & 3.7 & Fused \\
\hline Humerus & Medial epicondyle & $112-126$ & $3.7-4.2$ & Fused \\
\hline Radius & Proximal & 196 & 6.5 & Fused \\
\hline Femur & Greater trochanter & $196-232$ & $6.5-7.7$ & Fused \\
\hline Metacarpus & Distal epiphysis II-V & $203-280$ & $6.8-9.3$ & Fused \\
\hline Femur & Femoral head & $210-280$ & $7-9.3$ & Unfused \\
\hline Metatarsus & Distal epiphysis II-V & $224-308$ & $7.5-10.3$ & Fused \\
\hline Femur & Lesser trochanter & $238-308$ & $7.9-10.3$ & Fused \\
\hline Ulna & Proximal (tuberosity of olecranon & $266-364$ & $8.9-12.1$ & Fused \\
\hline Tibia & Distal epiphysis & $280-364$ & $9.3-12.1$ & Fused \\
\hline Fibula & Distal epiphysis & $280-392$ & $9.3-13$ & Fused \\
\hline Tibia & Proximal epiphysis & $350-532$ & $11.7-17.7$ & Unfused \\
\hline Tibia & Tibial tuberosity & $350-532$ & $11.7-17.7$ & Unfused \\
\hline Fibula & Proximal epiphysis & $378-504$ & $12.6-16.8$ & Unfused \\
\hline Femur & Distal epiphysis & $379-532$ & $12.6-17.7$ & Unfused \\
\hline Radius & Distal & $406-616$ & $13.5-20.5$ & Unfused \\
\hline Ulna & Distal epiphysis & $406-700$ & $13.5-23.3$ & Unfused \\
\hline Humerus & Proximal epiphysis & $547-730$ & $18.2-24.3$ & Unfused \\
\hline
\end{tabular}

Almost all skeletal elements of the cat were preserved (Figure 5). However, the skull was smashed into pieces, apparently because of the collapse of the grave and therefore it is not available for further studies. Therefore, except for the cranial skeleton, it was possible to take morphometric measurements from all other skeletal parts (i.e., mandible, scapula, humerus, radius, ulna, ossa coxae, femur, tibia, fibula, talus, calcaneus, metapodiums, atlas, axis and os sacrum). The obtained morphometric measurements and their comparison with the measurements of domestic and wild cats (given as mandible measurements only) from different archaeological sites are presented in the tables (Tables 3-13). Moreover, the Angora cat data were used in morphometric comparisons with modern cats.

To make the comparison more reliable, the bone measurements of the Balatlar cat were further compared with the raw measurements of the wild cat and domestic cat by using Z-scores. In particular, the greatest length (GL) values of the bones, which are thought to be more effective in predicting visual morphological characters of a species, were used for Z-score calculations. In this way, together with the raw morphometric values, the Z-score presented how many units of the GL value deviated in the negative or positive direction from the average mean of the domestic and wild cat data. 


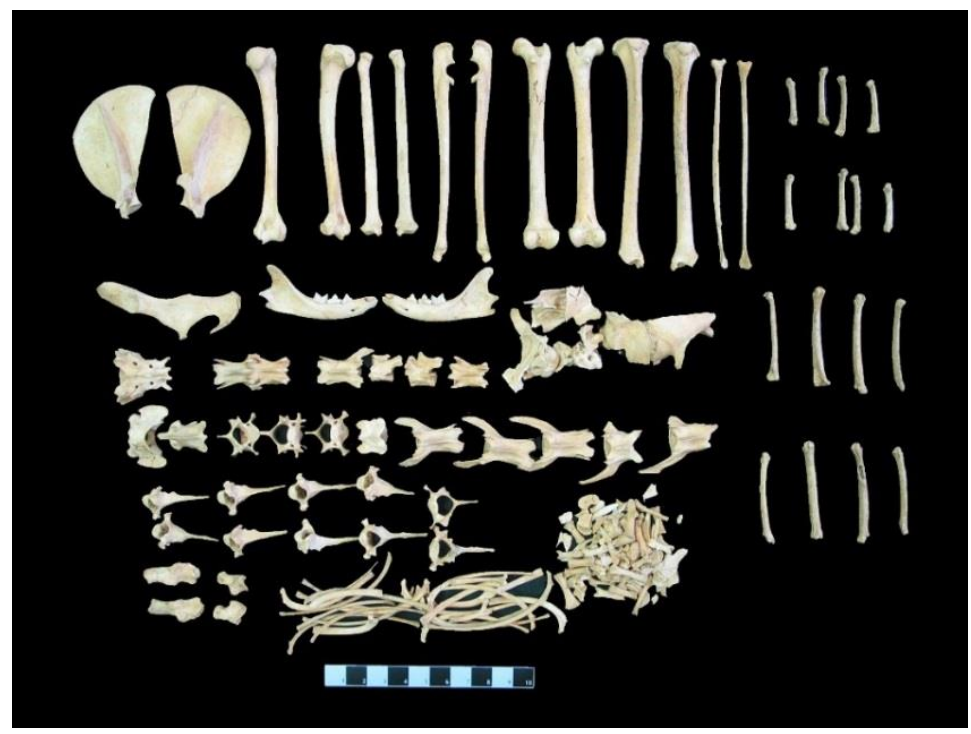

Figure 5. The skeletal remains of the Balatlar cat.

Table 3. The mandible measurements of the Balatlar cat in comparison with literature data.

\begin{tabular}{|c|c|c|c|c|c|c|c|c|c|}
\hline $\begin{array}{l}\text { Measure } \\
\text { Number }\end{array}$ & Bodyside & $\begin{array}{c}\text { Balatlar } \\
\text { Cat }\end{array}$ & $\begin{array}{c}\text { Angora } \\
\text { Cat } *\end{array}$ & $\begin{array}{c}\text { von den } \\
\text { Driesch and } \\
\text { Boessneck } \\
\text { 1983, Felis } \\
\text { silvestris } f \text {. } \\
\text { catus }\end{array}$ & $\begin{array}{l}\text { Kratochvil } \\
\text { 1973, Felis } \\
\text { silvestris } f \text {. } \\
\quad \text { catus }\end{array}$ & $\begin{array}{c}\text { Kratochvil } \\
\text { 1973, Felis s. } \\
\text { silvestris }\end{array}$ & $\begin{array}{c}\text { Teichert } \\
\text { 1978, Felis } \\
\text { silvestris } f \text {. } \\
\text { catus }\end{array}$ & $\begin{array}{l}\text { Teichert } \\
\text { 1978, Felis } \\
\text { silvestris } \\
\text { silvestris }\end{array}$ & $\begin{array}{c}\text { Guintard } \\
\text { and Arnaud } \\
\text { 2003, Felis } \\
\text { catus }\end{array}$ \\
\hline 1 & $\begin{array}{l}\text { Left } \\
\text { Right }\end{array}$ & $\begin{array}{l}55.01 \\
54.52\end{array}$ & $\begin{array}{l}63.55 \\
62.31\end{array}$ & 72.00 & 57.27 & 66.34 & 61.40 & 63.70 & 58.50 \\
\hline $\begin{array}{l}\text { Total } \\
\text { length } \\
\text { (no:1) }\end{array}$ & $\begin{array}{l}\text { Z-score } \\
\text { (F.C) } \\
\text { Z-score } \\
\text { (F.S) }\end{array}$ & $\begin{array}{l}-1.292 \\
-1.127\end{array}$ & 1.216 & & -0.524 & 0.781 & 0.746 & 0.345 & -0.146 \\
\hline 2 & $\begin{array}{l}\text { Left } \\
\text { Right }\end{array}$ & $\begin{array}{l}51.52 \\
51.61\end{array}$ & $\begin{array}{l}57.91 \\
58.30\end{array}$ & 67.00 & 53.43 & 62.65 & 59.40 & 62.20 & 55.80 \\
\hline 3 & $\begin{array}{c}\text { Left } \\
\text { Right }\end{array}$ & $\begin{array}{l}48.37 \\
48.51\end{array}$ & $\begin{array}{l}56.38 \\
57.04\end{array}$ & 64.00 & 50.31 & 58.21 & 54.40 & 55.80 & 51.30 \\
\hline 4 & $\begin{array}{c}\text { Left } \\
\text { Right }\end{array}$ & $\begin{array}{l}44.96 \\
45.33\end{array}$ & $\begin{array}{l}51.25 \\
51.50\end{array}$ & & 46.63 & 54.63 & 52.10 & 54.50 & 49.10 \\
\hline 5 & $\begin{array}{l}\text { Left } \\
\text { Right }\end{array}$ & $\begin{array}{l}53.34 \\
53.51\end{array}$ & $\begin{array}{l}60.26 \\
60.35\end{array}$ & 69.00 & 55.48 & 65.46 & 61.60 & 65.20 & 57.20 \\
\hline 6 & $\begin{array}{c}\text { Left } \\
\text { Right }\end{array}$ & $\begin{array}{l}52.80 \\
52.84\end{array}$ & $\begin{array}{l}60.81 \\
60.44\end{array}$ & 69.00 & & & & & \\
\hline 7 & $\begin{array}{c}\text { Left } \\
\text { Right }\end{array}$ & $\begin{array}{l}54.06 \\
53.99 \\
\end{array}$ & $\begin{array}{l}60.40 \\
60.95 \\
\end{array}$ & & 58.31 & 66.10 & 64.10 & 64.70 & \\
\hline 8 & $\begin{array}{l}\text { Left } \\
\text { Right }\end{array}$ & $\begin{array}{l}53.33 \\
53.53\end{array}$ & $\begin{array}{l}53.78 \\
53.61\end{array}$ & & 48.74 & 57.51 & 54.30 & 57.60 & \\
\hline 9 & $\begin{array}{l}\text { Left } \\
\text { Right }\end{array}$ & $\begin{array}{l}18.89 \\
18.96\end{array}$ & $\begin{array}{l}19.59 \\
19.22\end{array}$ & 21.00 & 18.41 & 21.70 & 20.00 & 21.20 & 18.90 \\
\hline 10 & $\begin{array}{l}\text { Left } \\
\text { Right }\end{array}$ & $\begin{array}{l}7.16 \\
7.15 \\
\end{array}$ & $\begin{array}{l}6.23 \\
6.31 \\
\end{array}$ & 8.00 & 7.00 & 8.55 & 7.30 & 8.50 & 7.20 \\
\hline 11 & $\begin{array}{l}\text { Left } \\
\text { Right }\end{array}$ & $\begin{array}{l}3.18 \\
3.20\end{array}$ & $\begin{array}{l}3.12 \\
3.19\end{array}$ & 3.00 & 3.20 & 3.73 & 3.10 & 3.60 & 3.10 \\
\hline 12 & $\begin{array}{l}\text { Left } \\
\text { Right }\end{array}$ & $\begin{array}{l}7.78 \\
8.19\end{array}$ & $\begin{array}{l}7.02 \\
7.19\end{array}$ & 64.00 & & & & & 7.00 \\
\hline 13 & $\begin{array}{c}\text { Left } \\
\text { Right }\end{array}$ & $\begin{array}{l}11.89 \\
11.93\end{array}$ & $\begin{array}{l}12.67 \\
12.78\end{array}$ & & 11.29 & 13.39 & 12.50 & 13.00 & \\
\hline
\end{tabular}


Table 3. Cont.

\begin{tabular}{|c|c|c|c|c|c|c|c|c|c|}
\hline $\begin{array}{l}\text { Measure } \\
\text { Number }\end{array}$ & Bodyside & $\begin{array}{c}\text { Balatlar } \\
\text { Cat }\end{array}$ & $\begin{array}{c}\text { Angora } \\
\text { Cat } *\end{array}$ & $\begin{array}{c}\text { von den } \\
\text { Driesch and } \\
\text { Boessneck } \\
\text { 1983, Felis } \\
\text { silvestris } f \text {. } \\
\text { catus }\end{array}$ & $\begin{array}{c}\text { Kratochvil } \\
\text { 1973, Felis } \\
\text { silvestris } f . \\
\text { catus }\end{array}$ & $\begin{array}{l}\text { Kratochvil } \\
\text { 1973, Felis s. } \\
\text { silvestris }\end{array}$ & $\begin{array}{c}\text { Teichert } \\
\text { 1978, Felis } \\
\text { silvestris } f \text {. } \\
\text { catus }\end{array}$ & $\begin{array}{l}\text { Teichert } \\
\text { 1978, Felis } \\
\text { silvestris } \\
\text { silvestris }\end{array}$ & $\begin{array}{c}\text { Guintard } \\
\text { and Arnaud } \\
\text { 2003, Felis } \\
\text { catus }\end{array}$ \\
\hline 14 & $\begin{array}{l}\text { Left } \\
\text { Right }\end{array}$ & $\begin{array}{l}23.76 \\
23.75\end{array}$ & $\begin{array}{l}27.25 \\
27.82\end{array}$ & 29.00 & 23.54 & 28.32 & 25.50 & 28.50 & 25.00 \\
\hline 15 & $\begin{array}{l}\text { Left } \\
\text { Right }\end{array}$ & $\begin{array}{l}9.88 \\
9.78 \\
\end{array}$ & $\begin{array}{l}10.66 \\
10.25\end{array}$ & 12.00 & 10.10 & 11.89 & 11.40 & 11.40 & 9.80 \\
\hline 16 & $\begin{array}{l}\text { Left } \\
\text { Right }\end{array}$ & $\begin{array}{l}8.51 \\
8.39\end{array}$ & $\begin{array}{l}10.45 \\
10.02\end{array}$ & & 9.38 & 11.15 & 10.30 & 10.70 & \\
\hline 17 & $\begin{array}{l}\text { Left } \\
\text { Right }\end{array}$ & $\begin{array}{l}8.86 \\
8.93\end{array}$ & $\begin{array}{l}10.28 \\
10.37\end{array}$ & & & & & & 9.60 \\
\hline 18 & $\begin{array}{l}\text { Left } \\
\text { Right }\end{array}$ & $\begin{array}{l}23.85 \\
23.84 \\
\end{array}$ & $\begin{array}{l}26.05 \\
26.05\end{array}$ & & 25.00 & 28.58 & 27.80 & 27.90 & \\
\hline 19 & $\begin{array}{l}\text { Left } \\
\text { Right }\end{array}$ & $\begin{array}{l}30.28 \\
30.30\end{array}$ & $\begin{array}{l}32.23 \\
32.65\end{array}$ & & & & & & 32.60 \\
\hline
\end{tabular}

* Reference collection; F.C: Felis silvestris f. catus; F.S: Felis silvestris silvestris.

Table 4. The scapula measurements of the Balatlar cat in comparison with literature data.

\begin{tabular}{|c|c|c|c|c|c|c|c|c|c|c|}
\hline SCAPULA & Bodyside & 1 & $\begin{array}{c}\text { Height Along } \\
\text { the Spine (n.1), } \\
\text { Z-Score }\end{array}$ & 2 & 3 & 4 & 5 & 6 & 7 & 10 \\
\hline \multirow[b]{2}{*}{ BALATLAR CAT } & Left & 64.06 & \multirow[b]{2}{*}{-0.978} & 63.27 & 44.64 & 10.86 & 11.97 & 10.89 & 7.89 & 58.34 \\
\hline & Right & 64.15 & & 63.58 & 44.75 & 10.90 & 12.07 & 10.95 & 7.76 & 58.41 \\
\hline \multirow{2}{*}{ ANGORA CAT * } & Left & 79.41 & \multirow{2}{*}{0.876} & 77.28 & 55.35 & 13.54 & 15.02 & 13.23 & 10.05 & 73.07 \\
\hline & Right & 79.56 & & 77.39 & 55.27 & 13.65 & 15.10 & 13.23 & 10.01 & 73.20 \\
\hline von den Driesch and Boessneck & Left & 79.00 & \multirow[b]{2}{*}{0.848} & 82.00 & & 13.70 & 16.50 & 15.00 & 10.70 & \\
\hline $\begin{array}{c}1983 \\
\text { Felis silvestris f. catus }\end{array}$ & Right & 79.50 & & 82.50 & & 13.50 & 16.00 & 14.50 & 10.50 & \\
\hline $\begin{array}{c}\text { Kratochvil 1976, Felis silvestris } f \text {. } \\
\text { catus } q\end{array}$ & Mean & 66.02 & -0.747 & & 48.70 & 11.61 & 13.16 & 11.06 & 8.69 & 61.23 \\
\hline
\end{tabular}

Table 5. The humerus measurements of the Balatlar cat in comparison with literature data.

\begin{tabular}{|c|c|c|c|c|c|c|c|c|}
\hline Humerus & Bodyside & 1 & $\begin{array}{l}\text { Greatest Length } \\
\text { (no.1), Z-Score }\end{array}$ & 3 & 4 & 5 & 6 & 7 \\
\hline \multirow{2}{*}{ BALATLAR CAT } & Left & 92.96 & \multirow[b]{2}{*}{-0.785} & 92.38 & 14.11 & 18.44 & 5.55 & 15.73 \\
\hline & Right & 93.02 & & 92.40 & 14.71 & 18.05 & 5.59 & 15.63 \\
\hline \multirow{2}{*}{ ANGORA CAT * } & Left & 101.77 & \multirow{2}{*}{0.075} & 100.46 & 16.87 & 20.73 & 8.34 & 20.02 \\
\hline & Right & 102.12 & & 100.52 & 17.06 & 20.37 & 8.17 & 19.68 \\
\hline \multirow{2}{*}{$\begin{array}{l}\text { von den Driesch and Boessneck 1983, } \\
\text { Felis silvestris f. catus }\end{array}$} & Left & 115.50 & \multirow{2}{*}{1.386} & 114.00 & & 24.80 & 8.80 & 20.20 \\
\hline & Right & 115.70 & & 114.00 & & 24.50 & 9.00 & 20.30 \\
\hline Kratochvil 1976, Felis silvestris f. catus + & Mean & 94.13 & -0.676 & & & 19.66 & 6.33 & 17.34 \\
\hline
\end{tabular}

* Reference collection.

The morphometric measurements of the skeletal remains of the Balatlar cat did not suggest it was a large sized cat. Instead, with it showing characteristics of a young female individual, the animal appeared to be a regular sized house cat.

The thoracic and pelvic limbs were found to be thin and slender according to the calculations obtained from the long bone indices (humerus, radius, femur and tibia indices) (Table 14). Being a young individual, in addition to perhaps the sex of the animal could both have had an effect on this. No pathological marks or health problems were observed 
during the careful macroscopic examination on the skeletal remains. This all suggested the individual to be a regular-sized normal healthy female house cat.

Table 6. The radius and ulna measurements of the Balatlar cat in comparison with literature data.

\begin{tabular}{|c|c|c|c|c|c|c|c|c|}
\hline & Measurements> & Body Side & 1 & Greatest Length (no.1), Z-Score & 2 & 3 & 4 & 5 \\
\hline \multirow{7}{*}{ Radius } & BAI ATI AR CAT & Left & 88.74 & \multirow{2}{*}{-0.826} & 6.87 & 5.35 & 5.48 & 11.44 \\
\hline & BALAILAK CAI & Right & 89.86 & & 6.84 & 5.32 & 5.26 & 11.43 \\
\hline & & Left & 99.57 & \multirow{2}{*}{0.429} & 8.00 & 6.05 & 6.43 & 12.84 \\
\hline & ANGORA CAT * & Right & 99.89 & & 8.24 & 6.04 & 6.41 & 12.93 \\
\hline & $\begin{array}{l}\text { von den Driesch and } \\
\text { Boessneck } 1983\end{array}$ & Left & 107.50 & \multirow{2}{*}{1.212} & 9.60 & & 6.00 & 13.80 \\
\hline & $\begin{array}{l}\text { Doessneck } 1983 \text {, } \\
\text { Felis silvestris } f \text {. catus }\end{array}$ & Right & 105.00 & & 9.50 & & 6.30 & 14.20 \\
\hline & $\begin{array}{c}\text { Kratochvil 1976, Felis silvestris } \\
\text { f. catuso }\end{array}$ & Mean & 89.38 & -0.816 & 7.70 & 5.60 & 5.03 & 12.00 \\
\hline \multirow{7}{*}{ Ulna } & & Left & 104.10 & \multirow{2}{*}{0.316} & 9.60 & 10.55 & 9.29 & 8.55 \\
\hline & BALATLAR CAI & Right & 105.29 & & 10.89 & 10.23 & 9.25 & 8.56 \\
\hline & & Left & 115.69 & \multirow{2}{*}{0.785} & 11.14 & 12.11 & 10.57 & 9.85 \\
\hline & ANGUKA CAI " & Right & 115.95 & & 11.42 & 11.98 & 10.59 & 9.78 \\
\hline & von den Driesch and & Left & & \multirow{2}{*}{-1.466} & & 13.50 & \multirow{3}{*}{11.70} & 11.00 \\
\hline & Felis silvestris $f$. catus & Right & 125.00 & & & 13.00 & & 10.50 \\
\hline & $\begin{array}{c}\text { Kratochvil 1976, Felis silvestris } \\
\text { f. catus? }\end{array}$ & Mean & 105.88 & 0.366 & & 10.41 & & 8.37 \\
\hline
\end{tabular}

* Reference collection.

Table 7. The ossa coxae measurements of the Balatlar cat and its comparison with literature data.

\begin{tabular}{|c|c|c|c|c|c|c|c|c|c|}
\hline COXAE & Bodyside & 1 & $\begin{array}{l}\text { Greatest Length of One } \\
\text { Half (No.1), Z-Score }\end{array}$ & 2 & 3 & 4 & 5 & 6 & 7 \\
\hline BALATLAR CAT & $\begin{array}{l}\text { Left } \\
\text { Right }\end{array}$ & 72.25 & -1.129 & 10.74 & 9.44 & & 9.58 & 4.18 & 18.96 \\
\hline ANGORA CAT * & $\begin{array}{l}\text { Left } \\
\text { Right }\end{array}$ & $\begin{array}{l}84.38 \\
83.91\end{array}$ & 0.692 & $\begin{array}{l}13.80 \\
12.72\end{array}$ & $\begin{array}{l}11.12 \\
11.06\end{array}$ & $\begin{array}{l}34.86 \\
34.62\end{array}$ & $\begin{array}{l}12.68 \\
12.76\end{array}$ & $\begin{array}{l}5.72 \\
5.34\end{array}$ & $\begin{array}{l}21.07 \\
21.33\end{array}$ \\
\hline $\begin{array}{l}\text { von den Driesch and } \\
\text { Boessneck 1983, } \\
\text { Felis silvestris f. catus }\end{array}$ & $\begin{array}{l}\text { Left } \\
\text { Right }\end{array}$ & $\begin{array}{l}86.00 \\
86.00\end{array}$ & 0.977 & & $\begin{array}{l}14.00 \\
14.00\end{array}$ & & & & \\
\hline $\begin{array}{c}\text { Kratochvil 1976, Felis silvestris } \\
\text { f. catus }+\end{array}$ & Mean & 76.10 & -0.540 & & 10.51 & 27.14 & 10.42 & 4.35 & \\
\hline
\end{tabular}

${ }^{*}$ Reference collection.

Table 8. The femur measurements of the Balatlar cat in comparison with literature data.

\begin{tabular}{|c|c|c|c|c|c|c|c|}
\hline Femur & Bodyside & 1 & $\begin{array}{l}\text { Greatest Length } \\
\text { (no.1), Z-Score }\end{array}$ & 2 & 3 & 4 & 5 \\
\hline \multirow{2}{*}{ BALATLAR CAT } & Left & 101.71 & \multirow{2}{*}{-0.791} & 18.29 & 8.76 & 7.38 & 16.89 \\
\hline & Right & 102.16 & & 18.57 & 8.85 & 7.41 & 17.20 \\
\hline \multirow{2}{*}{ ANGORA CAT * } & Left & 112.34 & \multirow{2}{*}{0.169} & 21.01 & 10.38 & 9.95 & 19.02 \\
\hline & Right & 113.14 & & 21.02 & 10.39 & 10.16 & 19.11 \\
\hline \multirow{2}{*}{$\begin{array}{l}\text { von den Driesch and Boessneck 1983, } \\
\text { Felis silvestris f. catus }\end{array}$} & Left & 126.50 & \multirow[b]{2}{*}{1.348} & 23.00 & & 11.00 & 22.00 \\
\hline & Right & 125.50 & & 22.80 & & 10.50 & 21.00 \\
\hline $\begin{array}{c}\text { Kratochvil 1976, Felis silvestris } f \text {. } \\
\text { catus }+\end{array}$ & Mean & 102.66 & -0.727 & 19.51 & 9.48 & 7.99 & 17.84 \\
\hline
\end{tabular}


Table 9. The tibia measurements of the Balatlar cat in comparison with literature data.

\begin{tabular}{|c|c|c|c|c|c|c|c|}
\hline Tibia & Bodyside & 1 & $\begin{array}{l}\text { Greatest Length } \\
\text { (no.1), Z-Score }\end{array}$ & 2 & 3 & 4 & 5 \\
\hline \multirow[b]{2}{*}{ BALATLAR CAT } & Left & 109.30 & \multirow{2}{*}{-0.740} & 17.94 & 6.84 & 12.92 & 8.99 \\
\hline & Right & 109.27 & & 17.94 & 6.66 & 13.45 & 8.95 \\
\hline \multirow{2}{*}{ ANGORA CAT * } & Left & 117.87 & \multirow[b]{2}{*}{0.209} & 21.04 & 8.36 & 14.89 & \multirow[t]{4}{*}{10.01} \\
\hline & Right & 116.72 & & 20.98 & 8.48 & 14.65 & \\
\hline von den Driesch and Boessneck 1983, & Left & 126.50 & \multirow{2}{*}{1.330} & 22.50 & 9.50 & 16.00 & \\
\hline Felis silvestris f. catus & Right & 127.00 & & 22.50 & 9.50 & 16.00 & \\
\hline 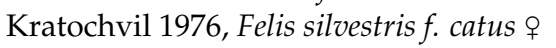 & Mean & 108.78 & -0.800 & 18.78 & 6.92 & & 9.17 \\
\hline
\end{tabular}

* Reference collection.

Table 10. The fibula measurements of the Balatlar cat in comparison with literature data.

\begin{tabular}{|c|c|c|c|}
\hline Fibula & & 1 & Greatest Length (no.1), Z-Score \\
\hline BALATLAR CAT & $\begin{array}{l}\text { Left } \\
\text { Right }\end{array}$ & $\begin{array}{l}101.93 \\
101.17\end{array}$ & -0.771 \\
\hline ANGORA CAT * & $\begin{array}{l}\text { Left } \\
\text { Right }\end{array}$ & $\begin{array}{l}110.63 \\
110.99\end{array}$ & 0.283 \\
\hline $\begin{array}{l}\text { von den Driesch and Boessneck 1983, } \\
\text { Felis silvestris f. catus }\end{array}$ & $\begin{array}{l}\text { Left } \\
\text { Right }\end{array}$ & 119.7 & 1.294 \\
\hline Kratochvil 1976, Felis silvestris f. catus + & Mean & 101.24 & -0.806 \\
\hline
\end{tabular}

* Reference collection.

Table 11. The astragalus and calcaneus measurements of the Balatlar cat in comparison with literature data.

\begin{tabular}{|c|c|c|c|c|c|c|}
\hline Bone> & & AST & $\begin{array}{c}\text { Greatest Length } \\
\text { (no.1) }\end{array}$ & CAL & $\begin{array}{c}\text { Greatest } \\
\text { Length (no.1) }\end{array}$ & CAL \\
\hline Measurements> & & 1 & Z-Score & 1 & Z-Score & 2 \\
\hline BALAT CAT & $\begin{array}{l}\text { Left } \\
\text { Right }\end{array}$ & $\begin{array}{l}14.42 \\
14.44\end{array}$ & -1.040 & $\begin{array}{c}26.4 \\
26.57\end{array}$ & -1.194 & $\begin{array}{c}10.88 \\
11.8\end{array}$ \\
\hline ANGORA CAT * & $\begin{array}{l}\text { Left } \\
\text { Right }\end{array}$ & $\begin{array}{l}16.28 \\
16.12\end{array}$ & 0.954 & $\begin{array}{l}30.29 \\
30.33\end{array}$ & 0.588 & $\begin{array}{l}12.63 \\
12.71\end{array}$ \\
\hline $\begin{array}{c}\text { von den Driesch and } \\
\text { Boessneck 1983, } \\
\text { Felis silvestris f. catus }\end{array}$ & $\begin{array}{l}\text { Left } \\
\text { Right }\end{array}$ & & & $\begin{array}{l}31.00 \\
31.50\end{array}$ & 1.026 & $\begin{array}{l}13.30 \\
14.00\end{array}$ \\
\hline $\begin{array}{c}\text { Kratochvil 1976, Felis } \\
\text { silvestris f. catus } q\end{array}$ & Mean & 15.43 & 0.086 & 28.15 & -0.420 & 11.57 \\
\hline
\end{tabular}

* Reference collection: AST: Astragalus; CAL: Calcaneus.

An astonishing finding is the presence of the other animals' remains, found together with those of the cat. The cat skeleton was unearthed in the anatomical composition as an articulated skeleton. The area corresponding with the abdominal organs location was occupied by the remains of a bird and a rodent, in the topographical location of the stomach in a living animal (see Figure 6). The lack of digestive marks (typical of biting or chewing) on the bones suggests that both skeletons were from the cat's prey. Archaeozological analysis proved that the mentioned bone fragments belonged to the house sparrow (Passer domesticus) and the house rat (Rattus rattus). Both animals could have been captured by the cat shortly before its death. It seems to be impossible that the cat could have swallowed both animals whole; therefore, the evidence of them being within the grave is a little confusing. Maybe both forms of prey were buried together with the cat and its owner because of his social status, the unknown importance of the animals, or even as part of a form of ritual. On the other hand, the location of these findings in the context of the topographical anatomy of the cat-i.e., their presence in an area normally linked with the stomach position - provokes ambiguous interpretation of the phenomenon. 
Table 12. The metapodials measurements of the Balatlar cat in comparison with literature data.

\begin{tabular}{|c|c|c|c|c|c|c|c|c|}
\hline Metapodial Bone & Number> & & & 1 & 2 & 3 & 4 & 5 \\
\hline \multirow{8}{*}{ BALATLAR CAT } & \multirow{4}{*}{ Metacarpus } & \multirow{2}{*}{ Left } & GL & & 26.80 & 30.77 & 28.94 & 23.87 \\
\hline & & & $\mathrm{Bd}$ & & 4.55 & 4.79 & 4.26 & 4.40 \\
\hline & & \multirow{2}{*}{ Right } & GL & & 26.92 & 30.92 & 29.14 & 24.28 \\
\hline & & & $\mathrm{Bd}$ & & 4.49 & 4.85 & 4.31 & 4.31 \\
\hline & \multirow{4}{*}{ Metatarsus } & \multirow[b]{2}{*}{ Left } & GL & & 44.34 & 48.97 & 48.33 & 43.26 \\
\hline & & & $\mathrm{Bd}$ & & 4.65 & 5.98 & 5.77 & 5.00 \\
\hline & & \multirow{2}{*}{ Right } & GL & & 44.88 & 48.43 & 49.17 & 43.62 \\
\hline & & & $\mathrm{Bd}$ & & 4.71 & 5.68 & 5.28 & 4.80 \\
\hline \multirow{8}{*}{ ANGORA CAT * } & \multirow{4}{*}{ Metacarpus } & \multirow{2}{*}{ Left } & GL & & 30.14 & 34.72 & 33.45 & 27.66 \\
\hline & & & $\mathrm{Bd}$ & & 4.85 & 5.19 & 4.76 & 4.73 \\
\hline & & \multirow{2}{*}{ Right } & GL & & 30.39 & 34.95 & 33.57 & 27.92 \\
\hline & & & $\mathrm{Bd}$ & & 5.32 & 5.2 & 4.77 & 4.72 \\
\hline & \multirow{4}{*}{ Metatarsus } & \multirow{2}{*}{ Left } & GL & & 51.11 & 53.47 & 54.47 & 47.43 \\
\hline & & & $\mathrm{Bd}$ & & 5.2 & 6.32 & 5.73 & 5.89 \\
\hline & & \multirow{2}{*}{ Right } & GL & & 51.16 & 53.34 & 54.41 & 47.17 \\
\hline & & & $\mathrm{Bd}$ & & 5.04 & 6.18 & 5.58 & 5.63 \\
\hline \multirow{4}{*}{$\begin{array}{l}\text { von den Driesch } \\
\text { and Boessneck } \\
\text { 1983, Felis silvestris } \\
\text { f. Catus }\end{array}$} & \multirow{2}{*}{ Metacarpus } & & GL & 13.00 & 33.70 & 38.30 & 36.70 & 31.30 \\
\hline & & & $\mathrm{Bd}$ & & 5.30 & 5.80 & 5.50 & 4.90 \\
\hline & \multirow{2}{*}{ Metatarsus } & & GL & 53.30 & 53.30 & 58.80 & 58.50 & 56.30 \\
\hline & & & $\mathrm{Bd}$ & 5.70 & 5.80 & 7.00 & 6.20 & 5.00 \\
\hline \multirow{4}{*}{$\begin{array}{l}\text { Kratochvil 1976, } \\
\text { Felis silvestris } f . \\
\text { catus } 9\end{array}$} & \multirow{2}{*}{ Metacarpus } & & GL & 10.77 & 27.34 & 31.45 & 29.91 & 24.99 \\
\hline & & & $\mathrm{Bd}$ & & 4.24 & 4.36 & 4.09 & \\
\hline & \multirow{2}{*}{ Metatarsus } & & GL & & 43.75 & 48.09 & 48.80 & 46.70 \\
\hline & & & $\mathrm{Bd}$ & & 4.72 & 5.17 & 4.77 & 4.32 \\
\hline
\end{tabular}

${ }^{*}$ Reference collection. GL: greatest length.

Table 13. The atlas, epistropheus and sacrum measurements of the Balatlar cat in comparison with literature data.

\begin{tabular}{|c|c|c|c|c|c|c|c|c|c|c|}
\hline ATLAS & 1 & Z-Score (No.1) & 2 & 3 & 4 & 5 & 6 & 7 & & \\
\hline BALATLAR CAT & 30.08 & -1.057 & 18.98 & 21.35 & 15.18 & 16.42 & 8.50 & 13.24 & & \\
\hline ANGORA CAT * & 37.11 & 0.396 & 21.15 & 23.81 & 16.97 & 17.06 & 8.59 & 14.42 & & \\
\hline $\begin{array}{c}\text { von den Driesch and Boessneck 1983, } \\
\text { Felis silvestris f. catus }\end{array}$ & 41.00 & 1.199 & 23.30 & 25.00 & 18.50 & 20.00 & & & & \\
\hline Kratochvil 1976, Felis silvestris f. catuso & 32.59 & -0.538 & 16.62 & 21.32 & 15.01 & & & & & \\
\hline EPISTROPHEUS & 1 & Z-score (No.1) & 2 & 3 & 4 & 5 & 6 & 7 & 8 & 9 \\
\hline BALATLAR CAT & 22.67 & -0.761 & 23.01 & 14.64 & 14.98 & & 9.27 & 8.97 & 18.54 & 6.45 \\
\hline ANGORA CAT * & 25.38 & 0.146 & 28.78 & 15.90 & 18.19 & 16.94 & 10.30 & 10.32 & 21.13 & 7.41 \\
\hline $\begin{array}{c}\text { von den Driesch and Boessneck 1983, } \\
\text { Felis silvestris f. catus }\end{array}$ & 29.00 & 1.359 & 29.00 & 17.00 & 17.50 & & 11.50 & & & \\
\hline Kratochvil 1976, Felis silvestris f. catuso & 22.72 & -0.744 & & 15.13 & & & 11.11 & & 19.16 & 7.16 \\
\hline SACRUM & 1 & Z-score (No.1) & 2 & 3 & 4 & 5 & & & & \\
\hline BALATLAR CAT & 26.66 & -1.153 & 22.98 & 27.11 & 12.55 & 5.00 & & & & \\
\hline ANGORA CAT * & 32.63 & 0.524 & 26.26 & 29.15 & 14.09 & 6.26 & & & & \\
\hline $\begin{array}{c}\text { von den Driesch and Boessneck 1983, } \\
\text { Felis silvestris f. catus }\end{array}$ & 33.00 & 0.630 & & 28.00 & & & & & & \\
\hline Kratochvil 1976, Felis silvestris f. catuso & & & 24.40 & 27.70 & & & & & & \\
\hline
\end{tabular}


Table 14. The long bone indices of the Balatlar cat in comparison with literature data.

\begin{tabular}{|c|c|c|c|c|c|c|c|c|c|c|c|c|c|}
\hline \multirow{2}{*}{$\frac{\text { CAT }}{\text { BALATLAR CAT }}$} & \multicolumn{3}{|c|}{$\begin{array}{l}\text { Humerus } \\
\text { Index }\end{array}$} & \multirow{2}{*}{$\begin{array}{c}\begin{array}{c}\text { HI } \\
\text { Z-Score }\end{array} \\
-1.196\end{array}$} & \multicolumn{2}{|c|}{$\begin{array}{l}\text { Radius } \\
\text { Index }\end{array}$} & \multirow{2}{*}{$\begin{array}{c}\begin{array}{c}\text { RI } \\
\text { Z-Score }\end{array} \\
0.136 \\
\end{array}$} & \multicolumn{2}{|c|}{$\begin{array}{l}\text { Femur } \\
\text { Index }\end{array}$} & \multirow{2}{*}{$\begin{array}{c}\begin{array}{c}\text { FI } \\
\text { Z-Score }\end{array} \\
-1.153\end{array}$} & \multicolumn{2}{|c|}{$\begin{array}{l}\text { Tibia } \\
\text { Index }\end{array}$} & \multirow{2}{*}{$\begin{array}{c}\begin{array}{c}\text { TI } \\
\text { Z-Score }\end{array} \\
-1.006\end{array}$} \\
\hline & $\begin{array}{l}\text { Left } \\
\text { Right }\end{array}$ & $\begin{array}{l}5.97 \\
6.01\end{array}$ & 5.99 & & $\begin{array}{l}6.18 \\
5.85\end{array}$ & 6.02 & & $\begin{array}{l}7.26 \\
7.25\end{array}$ & 7.26 & & $\begin{array}{l}6.26 \\
6.09\end{array}$ & 6.18 & \\
\hline ANGORA CAT * & $\begin{array}{l}\text { Left } \\
\text { Right }\end{array}$ & $\begin{array}{l}8.19 \\
8.00\end{array}$ & 8.10 & 1.018 & $\begin{array}{l}6.46 \\
6.42\end{array}$ & 6.44 & 1.341 & $\begin{array}{l}8.86 \\
8.98\end{array}$ & 8.92 & 1.066 & $\begin{array}{l}7.09 \\
7.27\end{array}$ & 7.18 & 0.584 \\
\hline $\begin{array}{c}\text { von den Driesch and } \\
\text { Boessneck 1983, Felis } \\
\text { silvestris f. catus }\end{array}$ & $\begin{array}{l}\text { Left } \\
\text { Right }\end{array}$ & $\begin{array}{l}7.62 \\
7.78 \\
\end{array}$ & 7.70 & 0.598 & $\begin{array}{l}5.58 \\
6.00 \\
\end{array}$ & 5.79 & -0.523 & $\begin{array}{l}8.70 \\
8.37 \\
\end{array}$ & 8.54 & 0.558 & $\begin{array}{l}7.51 \\
7.48 \\
\end{array}$ & 7.50 & 1.093 \\
\hline $\begin{array}{l}\text { Kratochvil 1976, Felis } \\
\text { silvestris f. catus }+\end{array}$ & Mean & & 6.73 & -0.420 & & 5.64 & -0.954 & & 7.77 & -0.471 & & 6.39 & -0.672 \\
\hline
\end{tabular}

${ }^{*}$ Reference collection; HI: Humerus index; RI: Radius index; FI: Femur index; TI: Tibia index.

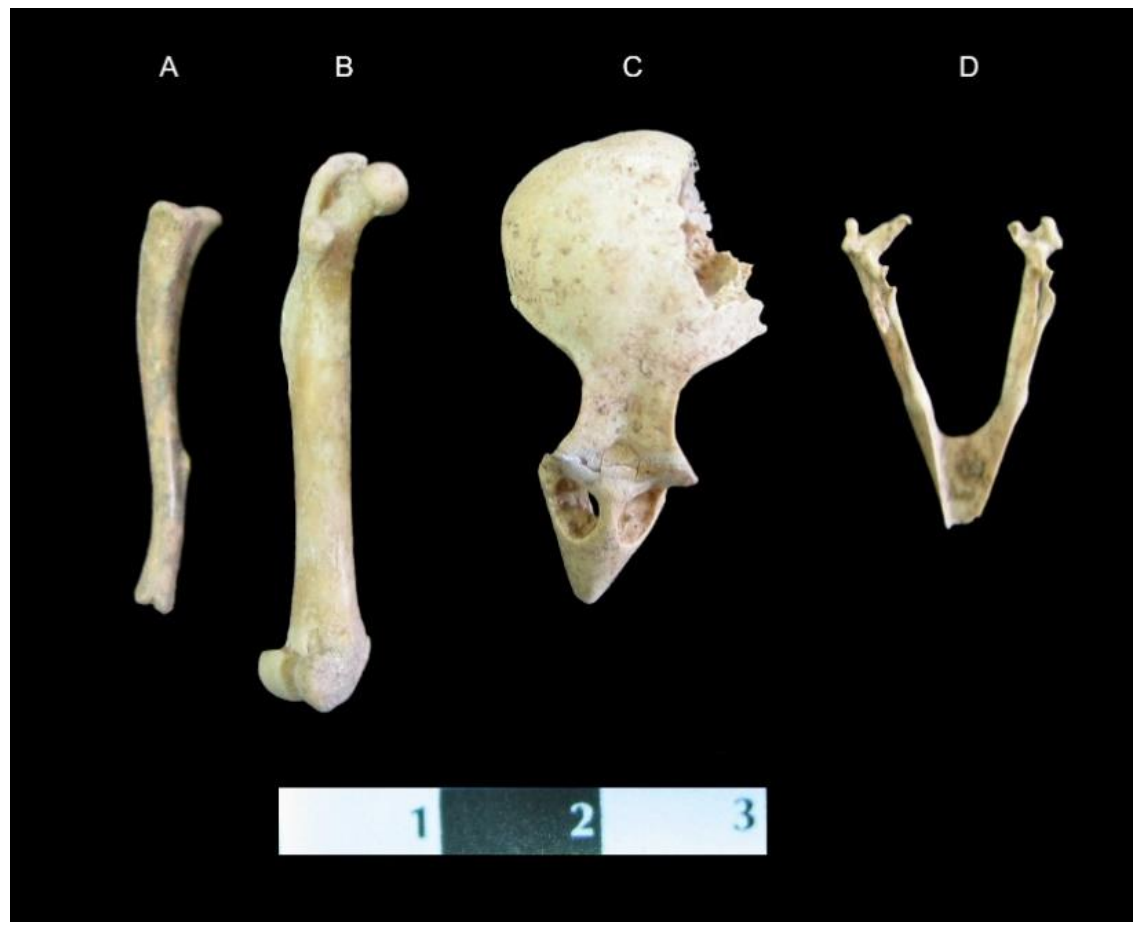

Figure 6. Skeletal remains recorded from the stomach of the Balatlar cat: A. Tibia of Rattus rattus; B. Femur of Rattus rattus; C. Skull of house sparrow (Passer domesticus); D. Mandible of house sparrow.

\section{Discussion}

The cat's skeleton, found in a burial chamber dating back to between the end of the 6th century and the first half of the 7th century, is an important finding in terms of the illustration of pet-human relationships occurring in the Early to Middle Byzantine period [33]. The fact that the cat — who spent its lifetime living around the feet of the human owner-was laying nearby to the thigh of apparently that same human individual within his/her grave, should be interpreted as a continuation of the inseparable union of these life companions. Observing the status of the burials in "2015-grave-14" chamber, it can be seen that the cat skeleton was carefully placed next to the right femur of the human individual, lying so that the head is pointed towards the west and the feet are pointed towards the east. The inhumation procedural accuracy in both cases (human and animal) seems to be fairly evident proof of the deliberate character of this intentional human activity. Moreover, the cat was placed in the same direction as that of the human corpse, showing evident signs of a bond and an inseparable human-cat relationship. 
Although the Romans were not deeply connected to domestic cats for various reasons [10], it is well known that domestic cats became common in Roman settlements by 100 BC [6,45]. Perhaps the status of cats as "pest controllers" of the households [5] was established by their function as rodent hunters. For this reason, the word "domestic cat" was not found in the important collection of agricultural lore Geoponica (6th century AD), nor was it mentioned by Columella (1st century AD), the prominent writer on agriculture in Roman times [5]. However, the relationship between human and domestic cats was present in far older periods [10]. In particular, the relationship gained more importance due to humans' preference to accept cats as pet animals since the 2nd to 5th century AD [6]. This new relationship contributed to the widespread acceptance of cats as pet animals in the human household, beyond being simple domestic animals. In this way, cats were eventually able to enter into humans' private sphere [9]. The human-cat relationship during the Roman period remained in the time periods that followed. In addition to their status as pet animals, they continued to fulfill their role as rodent controllers during the Byzantine period [26].

Alongside of being a domestic cat, the Balatlar cat probably played an active role in pest control as well. The cat was carefully placed in the human burial chamber, which is an indication of the status of the animal as a pet. The fact that the cat had captured and killed, or even eaten, a rat just before its death, could be a direct indicator of the cat's status as a rodent hunter. Moreover, the inhumation of the animal and human individual within the same grave in such a way as described above, provokes us to think that the cat must have been loved and adored by the human individual as a pet animal, beyond that of just being a simple domestic cat. This cat accompanied the human not only here, but also in the afterlife. Additionally, the cat probably hunted rodents as a continuation of its habit from the domestication process. On the other hand, birds were also kept as pet animals in the Roman times and since cats are alleged to be the killers of wild birds [10], this could represent another possible reason as to why there was a lack of preference for cats during the Roman times.

Although there was a scarcity of cat remains at archaeological sites dating back to the Roman period in Anatolia, for example, Didyma [20]; Pergamon [21]; Lidar Höyük [22]; Pessinus [23]; Troy [24] and Sagalassos [5], a very large assemblage of cat remains from the Yenikapi excavation site demonstrated that cats were significant in the life of the Byzantine capital city Constantinople $[27,29,30]$. This is an indication that the negative image of the cat during the Roman period [25] was gradually changing in the early Byzantine period as cats started to occupy a place in the social life of the Byzantine world. The context of being buried in the human grave, indeed, illustrates that the Balatlar cat had a comparatively higher status compared to other animals. Although the rat in cat's stomach could be a good indication of its active role in killing rodents in the household, the sparrow remains could suggest that the cat also ate and hunted wild species such as birds from outside. However, the lack evidence of mastication processes on the bone surfaces could undermine this hypothesis. However, this cat's hunting habit probably did not affect its status and affectionate relationship at home, since it would appear that it was buried in the very same grave as its possible owner.

Considering that pet animals can often blur the boundaries between animal and human status, and by being pampered can be treated like other human members of certain households [9], the Balatlar cat appeared to live in the household within these limits. Despite its special status in the household, the hunting habit of both rats and birds was probably an advantage to the household of keeping the cat. Careful examination of the skeletal remains also suggests that the mentioned cat is a normally grown, regular sized house animal, without any health or nutritional deficiency. In addition to the fact that the burial chamber had multiple corpses buried within it, and that the cat was buried next to the right leg of the individual who was buried, the latter suggests that the person was apparently the owner of the cat. Perhaps the good health status of the cat was also affected by the care it received from its owner. The fact that the cat was carefully placed in 
the same grave as its possible owner could provide proof of the close emotional bond [9] between them. It is also possible that the cat emphasized the social position of its owner and was placed in the grave as an indicator of the owner's status; a phenomenon often found in Medieval societies and cultures [9]. The most prominent example of this kind is the Byzantine Empress Zoe (11th century) and the cat that was most favorite pet [25]. During the time of the early medieval period, this was an extraordinary example of the status given to a pet animal.

The morphometrics of the skeletal remains revealed the Balatlar cat as a thin and slender domestic cat. In addition to being a young individual, its gender also probably had an effect on the morphological features of the skeleton. The status of being a young female individual probably also affected its visual morphological characteristics. Its osteometric measurements were very close to the values that Kratochvíl $(1973,1976)[37,38]$ and Teichert (1978) [39] established as being normal for female cats. In particular, when looking at the Z-score values for the "greatest length" measurements of the Balatlar cat, it was observed that these are almost the same in tone and level with the Z-scores obtained by using the raw data of domestic cats presented by Kratochvíl $(1973,1976)$ [37,38]. However, the Z-score of the Balatlar cat was different from the Z-scores of the Angora cat and the Roman house cat [36]. This was probably because it was a young female individual. The Balatlar cat was found to be smaller than the Roman house cat examined by von den Driesch and Boessneck (1983) [36], but this was probably because the Roman cat was a male individual. The examined cat also appeared to be a rather small individual when compared to the measurements of wild cats [36,39], since there were notable differences between their Z-scores. On the other hand, although it was a young individual, the animal exhibited characteristics of the final stage of morphological development, according to the times of the epiphyseal closure [44].

Moreover, the only explanation of the existence of a beloved cat and human (owner) in the same grave is that their death must have occurred simultaneously, or that the animal was killed intentionally. Given that there is no evidence that the cat was killed, it is also possible that following its natural death the cat was placed in its owner's grave. The ritual character of inhumation procedures and the existence of the offerings/prey status of the accompanying creatures (rat and sparrow) in the grave could also be potentially explained as the results of a multicultural fusion phenomenon, which occurred in the Roman Empire via the mixing of various traditions, religions, and cultures. It must be added, that such a remnant of the old pagan tradition was still alive in Slavic countries even in the 19th century, therefore, it is not unlikely for the period of Christianized Byzantine Empire that emerged from the Ancient World of polytheism.

\section{Conclusions}

In conclusion, the Balatlar cat illustrates that the status of cats reached a higher level in the Byzantine society than that in the Roman times. In addition to being a pet animal, it is also an unavoidable fact that the cat also engaged with hunting rodents and birds. The most important signature demonstrating the higher status of human-animal relationship is that the healthy female cat was synchronously placed in the same grave and in the same position as her possible human owner. This can be regarded as the most important example of a pet-human relationship recorded at any Byzantine site so far.

Author Contributions: Conceptualization, V.O., G.K. and A.B.S.; methodology, V.O. and A.B.S.; software, V.O. and A.B.S.; validation, V.O., G.K., A.B.S. and A.C.; formal analysis, V.O. and A.B.S.; investigation, V.O., G.K., A.A. and A.B.S.; resources, V.O., G.K. and Ö.E.Ö.; data curation, V.O., G.K., A.A., Ö.E.Ö. and A.B.S.; writing—original draft preparation, V.O., G.K. and A.B.S.; writingreview and editing, V.O., A.B.S. and A.C.; visualization, V.O. and G.K.; supervision, G.K.; project administration, V.O. All authors have read and agreed to the published version of the manuscript.

Funding: This research received no external funding; and the APC was supported by statutory research and development activity funds assigned to Wroclaw University of Environmental and Life Sciences. 
Informed Consent Statement: Ethical review and approval were waived for this study, since no animal was required to kill or any other ethical issues were associated with the study.

Data Availability Statement: The Balatlar cat and the Angora cat are available in the collections of the Osteoarchaeology Research Center, Istanbul University-Cerrahpaşa. Skeletal remains of the Balatlar cat are available for further study via application through the General Directorate of Cultural Heritage and Museums, Ministry of Culture and Tourism, Republic of Turkey. The datasets generated, analyzed, and used in this study will be provided by the corresponding author on request.

Conflicts of Interest: The authors declare no conflict of interest related to this study.

\section{References}

1. Hu, Y.; Hu, S.; Wang, W.; Wu, X.; Marshall, F.B.; Chen, X.; Hou, L.; Wang, C. Earliest Evidence for Commensal Processes of Cat Domestication. Proc. Natl. Acad. Sci. USA 2014, 111, 116-120. [CrossRef] [PubMed]

2. Linseele, V.; Van Neer, W.; Hendrickx, S. Evidence for Early Cat Taming in Egypt. J. Archaeol. Sci. 2007, 34, 2081-2090. [CrossRef]

3. Ottoni, C.; Van Neer, W.; De Cupere, B.; Daligault, J.; Guimaraes, S.; Peters, J.; Spassov, N.; Prendergast, M.E.; Boivin, N.; Morales-Muñiz, A.; et al. The Palaeogenetics of Cat Dispersal in the Ancient World. Nat. Ecol. Evol. 2017, 1, 139. [CrossRef]

4. Toynbee, J.M.C. Animals in Roman Life and Art; Cornell University Press: Ithaca, NY, USA, 1973; ISBN 978-0-8014-0785-7.

5. De Cupere, B. Animals at Ancient Sagalassos: Evidence of the Faunal Remains; Brepols: Turnhout, Belgium, 2001; ISBN 978-2-50351062-0.

6. Lazenby, F.D. Greek and Roman Household Pets. Class. J. 1949, 44, 299-307.

7. Von den Driesch, A. Kulturgeschichte der Hauskatze. In Krankheiten der Katze Band I; Schmidt, V., Horzinek, M., Eds.; Gustav Fischer Verlag: Jena, Germany, 1992; pp. 17-40.

8. Lewis, S.; Llewellyn-Jones, L. The Culture of Animals in Antiquity: A Sourcebook with Commentaries, 1st ed.; Routledge: Abingdonon-Thames, UK, 2018; ISBN 978-1-315-20160-3.

9. Walker-Meikle, K. Medieval Pets; Boydell Press: Woodbridge, Suffolk, UK; Rochester, NY, USA, 2012; ISBN 978-1-84383-758-9.

10. Faure, E.; Kitchener, A.C. An Archaeological and Historical Review of the Relationships between Felids and People. Anthrozoös 2009, 22, 221-238. [CrossRef]

11. Smith, C. Dogs, Cats and Horses in the Scottish Medieval Town. Proc. Soc. Antiqu. Scotl. 1998, 128, 859-885.

12. Bostock, J.; Riley, H.T. The Natural History of Pliny; BiblioLife: Charleston, SC, USA, 2009; ISBN 978-1117234632.

13. Lewis, C.O. Ancient Names of the Cat. Notes Queries 1859, S2-S8, 261-263. [CrossRef]

14. Donalson, M.D. The Domestic Cat in Roman Civilization; Edwin Mellen Press: Lewiston, NY, USA, 1999; ISBN 978-0-7734-8160-2.

15. Buglass, J.; West, J. Pet Cats in Roman Villas: A North Yorkshire Candidate? Archaeol. Forum J. CBA Yorks. 2014, 3, 85-102.

16. Van Neer, W.; Linseele, V.; Friedman, R.; De Cupere, B. More Evidence for Cat Taming at the Predynastic Elite Cemetery of Hierakonpolis (Upper Egypt). J. Archaeol. Sci. 2014, 45, 103-111. [CrossRef]

17. Vigne, J.-D. Early Taming of the Cat in Cyprus. Science 2004, 304, 259. [CrossRef]

18. Zeder, M.A. Pathways to animal domestication. In Biodiversity in Agriculture: Domestication, Evolution, and Sustainability; Gepts, P., Famula, T.R., Bettinger, R.L., Brush, S.B., Damania, A.B., McGuire, P.E., Qualset, C.O., Eds.; Cambridge University Press: Cambridge, UK, 2012; pp. 227-259. ISBN 978-1-139-01951-4.

19. Lentacker, A.; De Cupere, B. Domestication of the Cat and Reflections on the Scarcity of Finds in Archaeological Contexts. Colloq. Hist. Connaiss. Zool. 1994, 5, 69-78.

20. Boessneck, J.; Schäffer, J. Tierknochenfunde Aus Didyma II. Archäol. Anz. 1986, 2, 251-301.

21. Boessneck, J.; Von den Driesch, A. Knochenfunde Aus Zisternen in Pergamon; München Institut für Palaeoanatomie: Munich, Germany, 1985.

22. Kussinger, S. Tierknochenfunde Vom Lidar Höyük in Sudostanatolien (Grabungen 1979-1986). Ph.D. Thesis, University of Groningen, Münch, Germany, 1988.

23. Ervynck, A.; De Cupere, B.; Van Neer, W. Consumption refuse from the Byzantine castle at Pessinus, Central-Anatolia, Turkey. In Archaeozoology of the Near East. Proceedings of the First International Symposium on the Archaeozoology of Southwestern Asia and Adjacent Areas; Buitenhuis, A.T., Clason, H., Eds.; Universal Book Services: Leiden, The Netherlands, 1993; pp. $119-127$.

24. Fabiš, M. Archaeozoological Remains from the Lower Sanctuary. A Preliminary Report on the 1994 Excavations. Stud. Troica 1996, $6,217-227$.

25. Kislinger, E. Byzantine cats. In Animals in Enviroment in Byzantium (7th- 12 th c.); Anagnostakis, I., Kolias, T.G., Papadopoulou, E., Eds.; National Hellenic Research Foundation: Athens, Greece, 2011; pp. 165-178.

26. Kroll, H. Animals in the Byzantine Empire: An Overview of the Archaeozoological Evidence. Archeol. Mediev. 2012, XXXIX, 93-121.

27. Onar, V.; Alpak, H.; Pazvant, G.; Armutak, A.; Ince, N.G.; Kiziltan, Z. A Bridge from Byzantium to Modern Day Istanbul: An Overview of Animal Skeleton Remains Found during Metro and Marmaray Excavations. Istanb. Univ. J. Fac. Vet. Med. 2013, 39, $1-8$.

28. Onar, V.; Pazvant, G.; Armutak, A. Radiocarbon Dating Results of the Animal Remains Uncovered at Yenikapı Excavations. In 1st Symposium on Marmaray-Metro Salvage Excavations; Istanbul Archaeological Museum: Istanbul, Turkey, 2008; pp. $249-256$. 
29. Onar, V.; Pazvant, G.; Armutak, A.; Alpak, H.; Karamut, I.; Gökçay, M. Preliminary Report on the Animal Remains Uncovered at Yenikap1 Metro and Marmaray Excavations. In 1st Symposium on Marmaray-Metro Salvage Excavations; Istanbul Archaeological Museum: Istanbul, Turkey, 2008; pp. 223-231.

30. Onar, V.; Pazvant, G.; Alpak, H.; Ince, N.G.; Armutak, A.; Kiziltan, Z.S. Animal Skeletal Remains of the Theodosius Harbor: General Overview. Turk. J. Vet. Anim. Sci. 2013, 37, 81-85.

31. Köroğlu, G.; İnanan, F.; Korucu, F.; Güngür-Alper, E. Sinop Balatlar Yapı Topluluğu Kazılarında $2010-2015$ Yılları Arasında Sürdürülen Çalışmaların Genel Sonuçları. In Uluslararası XIX. Ortaçağ ve Türk Dönemi Kazıları ve Sanat Tarihi Araştırmaları Sempozyumu II; Türk Tarih Kurumu Yayınları 8: Ankara, Turkey, 2019; pp. 21-38.

32. Köroğlu, G. 2014 Yılı Sinop Balatlar Kilisesi Kazıları. Kazı Sonuç. Toplantısı 2015, 37, 463-476.

33. Köroğlu, G. 2015 Yılı Sinop Balatlar Kilisesi Kazıları. Kazı Sonuç. Toplantısı 2016, 38, 191-204.

34. Bryer, A.; Winfield, D. The Byzantine Monuments and Topography of the Pontos; Dumbarton Oaks Research Library and Collection: Washington, DC, USA, 1985; ISBN 978-0-88402-122-3.

35. Von den Driesch, A. A Guide to the Measurement of Animal Bones from Archaeological Sites; Peabody Museum of Archaeology and Ethnology Harward University: Cambridge, MA, USA, 1976; ISBN 9780873659505.

36. von den Driesch, A.; Boessneck, J. A Roman Cat Skeleton from Quseir on the Red Sea Coast. J. Archaeol. Sci. 1983, 10, $205-211$. [CrossRef]

37. Kratochvíl, Z. Schädelkritieren Der Wild- Und Hauskatze (Felis Silvestris Silvestris Schreb. 1777 Und F. s. f. Catus L. 1758). Acta Sci. Nat. Brno 1973, 7, 1-50.

38. Kratochvíl, Z. Das Postkranialskelett Der Wild- Und Hauskatze (Felis Silvestris Und F. Lybica F. Catus). Acta Sci. Nat. Brno 1976, 10, 1-43.

39. Teichert, M. Die Katzenknochen Aus Den Urgeschichtlichen Kulthöhlen Des Kyffhäusergebirges. Alt-Thüring 1978, 15 , 32-67.

40. Guintard, C.; Arnaud, S. Ostéologie Comparée de La Tête Osseuse Chez Trois Espèces de Félidés d'europe de l'ouest: Le Lynx (Lynx Lynx), Le Chat Sauvage (Felis Sylvestris) et Le Chat Domestique (Felis Catus). Bull. Soc. Sci. Nat. Lóuest Fr. 2003, 25, 49-83.

41. Berteaux, D.; Guintard, C. Osteometric Study of the Metapodials of Amsterdam Island Feral Cattle. Acta Theriol. 1995, 40, 97-110. [CrossRef]

42. Davis, S.J.M. The Effect of Castration and Age on the Development of the Shetland Sheep Skeleton and a Metric Comparison Between Bones of Males, Females and Castrates. J. Archaeol. Sci. 2000, 27, 373-390. [CrossRef]

43. Guintard, C. Ostéométrie Des Métapodes de Bovins. Osteometric Study of Cattle's Metapodial Bones. Rev. Med. Vet. 1998, 149, 751-770.

44. Smith, R.N. Fusion of Ossification Centres in the Cat. J. Small Anim. Pract. 1969, 10, 523-530. [CrossRef]

45. Hughes, J.D. Europe as Consumer of Exotic Biodiversity: Greek and Roman Times. Landsc. Res. 2003, 28, 21-31. [CrossRef] 